\title{
Modeling of a future scenario of potential sea level rise and consequences to land use in the Cananéia-Iguape Estuarine- Lagoonal Complex (Brazil)
}

\author{
Fabrício Bau DALMAS', Jose OJEDA ZÚJAR², Pablo FRAILE-JURADO², Antonio \\ Conceição PARANHOS FILHO ${ }^{3}$, Ana Paula Garcia OLIVEIRA4, Antonio Roberto SAAD¹ \& \\ Arlei Benedito MACEDO5 \\ 1 Universidade UNG. Programa de Mestrado em Análise Geoambiental. Praça Tereza Cristina, n 229, CEP \\ 07023-070, Guarulhos, SP, Brazil (fdalmas@prof.ung.br, saadhome@uol.com.br). \\ 2 Universidad de Sevilla. Departamento de Geografía Física y Análisis Geográfico Regional. Calle Doña \\ María de Padilla, 41004, Sevilla, Spain (zujar@us.es, pfraile@us.es). \\ ${ }^{3}$ Universidade Federal de Mato Grosso do Sul. Faculdade de Engenharias, Arquitetura e Urbanismo e \\ Geografia. Cidade Universitária, S/N, Caixa Postal 549, CEP 79070-900, Campo Grande, MS, Brazil \\ (antonio.paranhos@pq.cnpq.br). \\ ${ }^{4}$ Universidade Uniderp. Curso de Pós-Graduação em Meio Ambiente e Desenvolvimento Regional. Rua \\ Alexandre Herculado, no 1.400, CEP 73097-280, Campo Grande, MS, Brazil (apg.bio@gmail.com). \\ 5 Universidade de São Paulo. Instituto de Geociências. Cidade Universitária, Rua do Lago, n 562, CEP \\ 05508-080, São Paulo, SP, Brazil (abmacedo56@gmail.com).
}

\begin{abstract}
The objective of this study was to develop possible future land use scenarios for the Cananéia-Iguape Estuarine-Lagoonal Complex by the analysis of the land use evolution along 24 years (1986-2010), and to predict scenarios for 2025. In order to predict the scenario of the land use and occupation classes of 2025 a simulation was carried out by means of the Markov chain methods and calibration of the simulation model in the IDRISI Andes program. In the phase prior to this step it was utilized TM sensor scenes (Landsat 5) and supervised classification techniques to simulating the land use and occupation map of 2010 from land use and occupation maps from 1986 and 1999. Then the land use and occupation map of 2010 was utilized inside de Markov chain to simulate the map of 2025. By applying the techniques proposed by Titus and Narayanan, Pfeffer, Ramhstorf and the Intergovernmental Panel on Climate Change (IPCC) model, the vulnerability of the study area was calculated taking into consideration a potential sea level rise in 2025, 2050 and 2100. In the last step of the applied method, land use and occupation classes were assessed, which will possibly be affected by a highest tide event in 2025. It was observed that $80.92 \%$ the area flooded during highest tide events in 1999 was composed of dense arboreal vegetation and it is concluded that this expansion of the dense arboreal vegetation area will also occur towards the coastal zone in 2025. We suggest that the local factor for sea level rise in the study area has a strong geological component, so that, instead of a mere sea level rise, an opposite movement is taking place, which is the subsidence of the plain due to modern tectonism.
\end{abstract}

Keywords. Geotechnologies, Markov, Non-supervised Classification, Ribeira de Iguape Watersheda

Resumo. Modelagem de CENÁRIO FUtURO dE POTENCIAL AUMENTO NO NÍVEL DO MAR E SUAS CONSEQUÊNCIAS NO USO DO SOLO DO COMPLEXO ESTUARINO-LAGUNAR DE IGUAPE-CANANÉIA (BRASIL). O objetivo deste trabalho foi desenvolver possíveis cenários futuros de uso do solo do Complexo Estuarino-Lagunar de Iguape-Cananéia baseando-se na evolução deste uso durante 24 anos (1986 - 2010) e prever cenários para 2025. Com o intuito de prever o cenário das classes de uso e ocupação do solo de 2025 foi realizada uma simulação por meio dos métodos da cadeia de Markov e calibração do modelo de simulação, no programa IDRISI Andes. Na fase anterior a esta etapa foram utilizadas cenas do sensor TM (Landsat 5) e técnicas de classificação supervisionada para simular o mapa de uso e ocupação do solo de 2010 a partir de mapas de uso e ocupação do solo de 1986 e 1999. O mapa de uso e ocupação do solo 2010 foi utilizado dentro da cadeia de Markov para simular o mapa de 2025. Posteriormente, através da aplicação das técnicas de Titus e Narayanan, Pfeffer, Ramhstorf e modelo do Intergovernmental Panel on Climate Change, calculou-se a vulnerabilidade da área de estudo a um potencial aumento do nível do mar em 2025, 2050 e 2100. Na última fase da metodologia, foram avaliadas as 
classes de uso e ocupação do solo que possivelmente serão afetadas por um evento de máxima preamar, em 2025. Observou-se que em 1999, 80,92\% da área inundada em eventos de máxima preamar eram compostos por vegetação arbórea densa e conclui-se que essa expansão de área da vegetação arbórea densa também ocorrerá no sentido da zona litorânea, em 2025. Por fim, sugere-se fator local do aumento do nível na área de estudo pode ter forte geológica, de maneira que, ao contrário de apenas um aumento do nível do mar, pode estar ocorrendo um movimento contrário, afundamento da planície devido a movimentos tectônicos modernos.

Palavras-chave. Geotecnologias, Markov, Classificação não supervisionada, Bacia do Ribeira de Iguape

\section{Introduction}

To think about the course of man and his holistic development as a person sheds light the need to understand how the path of different societies and communities has evolved, so as to take well-based decisions that will lead to a sustainable evolution. Thus, by interpreting historical data, it is possible to trace the different scenarios regarding the past being studied, the present day and the desirable future (Gago, 2007).

Several experiences have shown that the building of scenarios helps planning groups modify and adjust their point of view regarding space, time and environment, leading to a better understanding of the primary problems and to communal solutions. Clavero et al. (2010) explain that the major utility of future scenarios is as tools for decision making, affecting social and environmental factors in a regional scale. The modeling of scenarios is a method that enables the study of the dynamics of land use changes. With a model, it is possible to simulate future landscape dynamics, having some established scenarios as basis.

The study of future scenarios cannot be considered the end of a management process, but a way to encourage decision making. The scenarios are guides that describe alternative routes to a possible future founded on reasonable hypotheses. They are intellectual exercises that help understand what can happen, and not what will happen, nor what must happen or what managers want to happen. The forms in which land uses are distributed will be the basis of the society evolution, constituting a first-order element in the search for the most adequate future environmental situation (Clavero et al., 2010).
Urbanization, a process that exerts a strong influence on the distribution of land use and occupation, is driven by economic growth, industrialization, agriculture development and the rise of urban population. As the number of inhabitants increases in the cities, there is an increase in number and size of urbanized areas, sometimes overlapping natural or productive areas, usually without a growth pattern adjusted to the physical environment (topography and rivers) and to socio-economic and political factors (legislation and land value), which interact among themselves (Antrop, 2004). Urbanization affects the structure and operation of ecosystems in many ways, modifying the natural land covers and in some cases causing impermeabilization with artificial covers. From the awareness of these effects, a necessity of developing and implementing urban planning strategies arises, starting from a better knowledge of the spatial patterns, the causes and impacts of urbanization, and the factors that control urban growth in certain zones (Angonese et al., 2010).

The simulation of future land use and occupation scenarios and urbanization is an important tool to assess future developments in complex systems characterized by a great number of uncertainties, and consequently it is a proper technique for management and planning of, for example, coastal zones. The scenarios help integrate socio-economic models with physical, chemical or biological models, reflect on trends and dynamics, and work with different time and spatial scales (Carrero et al., 2010). The elaboration of scenarios aids the presentation of long-term evolutionary trends (MMA, 2006).

Vieira (2010) applied the scenario method to check the changes that occurred in an environmental protection area of the Japi Ridge 
(State of São Paulo). The author concluded that the changes that occurred in this area evolved towards the conservation expectations, but not towards the configuration of forests predicted by the legal environmental acts. Therefore, the perspective proposed for the construction of scenarios can aid decision making in participative processes, particularly when the spatialization of expectations and comparison with other scenarios are in course, which helps when proposing consensual future scenarios that aim to establish environmental conservation and social sharing.

Terra (2010) worked with scenarios in order to interpret the accumulation of anthropic actions along 45 years and to estimate the possible effects of probable impacts in 2028. The study area is located in the southern coast of the State of São Paulo and encompasses the Despraiado Sustainable Development Reserve, the Juréia-Itatins Ecologic Station and the neighboring buffer zones to these two regions. The methodology applied by Terra (2010) was the landscape simulation using Markov chains. The conclusion of his research was that the scenario simulated for 2028 suggests that if the historical condition of land use and the State actions follow the same trend of the last 45 years, the Ecological Station, the Sustainable Development Reserve and the Buffer Zone neighboring areas will not have a natural vegetation cover that exceeds $10 \%$, but will be composed of $43 \%$. In terms of evolution of the natural vegetation, the Despraiado Sustainable Development Reserve is the most privileged region, because the simulated scenario shows that it will be a pioneer area of best future forest conservation state. However, in terms of concentration of cumulated effects, the values are worse than those obtained for the Ecological Station, which presents the best scenario in this aspect.

Angonese et al. (2010) studied the region of Gran San Miguel de Tucumán, located northeast of Argentina, by combining the Multi-Criteria Evaluation and the Geographical Information Systems techniques to generate an urban occupation model desirable for the period between 2001 and 2009. The model was compared to the actual growth in that period, making the evaluation for different desirable urban growth scenarios possible in the light of social, economic and environmental criteria. A digital elevation model and TM sensor images (from 2001 and 2009) were used to prepare the urban map, considering "urban" the surface with medium to high density of constructions. The proposed scenarios presented mean adequacy values higher than those observed for the actual urban growth. In general, the desirable areas for urban use according to the different scenarios are located east of Gran San Miguel de Tucumán. However, the actual growth is observed towards the central region of the study area, following the main transportation routes, which is a pattern similar to the extreme economic scenario, evidencing the influence of the road network in the location of residential areas and the lack of environmental preservation criteria when establishing urban zones.

When it comes to coastal areas, the mean sea level rise is a phenomenon that can lead to considerable economic, social and environmental losses. According to the data published in the last Intergovernmental Panel on Climate Change IPCC Report (IPCC, 2007) the sea level has risen at an annual rate of $1.8 \mathrm{~mm}( \pm 0.5 \mathrm{~mm})$ during the 1961-2003 period. These values were obtained from studies based on data recorded by tide gauges located at different points of the Earth's surface. The data is sent to the Permanent Service for Mean Sea Level - PSMSL. The IPCC studies show that the rise rates will continue to increase in the next century, reaching values that represent twice the rates recorded in the 20th century (regardless which scenario, with higher or lower intervention of greenhouse gas emissions). Sea level will continue to rise at annual rates between 2 and $3 \mathrm{~mm}$ during the first half of the $21^{\text {st }}$ century (Ojeda et al., 2009).

Concerned with the potential impacts resulting from the mean sea level rise, many supranational (the United Nations and the European Union) and national institutions (in Germany, Australia, and the United States of America) have developed different strategies and plans with the objective of identifying and quantifying the potential effects of the mean sea level rise (Fraile-Jurado, 2011). 
Many researchers, developing different methodologies, have been working on the quantification of the vulnerability of a potential mean sea level rise. Thus, a small rise of the ocean levels would suffice to trigger salinization of aquifers, flooding of coastal plains and destruction of urban areas (Barth \& Titus, 1984).

Since 1992, there has been the possibility of measuring the mean sea level using altimeters coupled with satellites, and the papers published using this information point to annual sea level rise rates of $3.1 \mathrm{~mm}$, with plus or minus variations of $0.7 \mathrm{~mm}$ (IPCC, 2007). Moreover, an intensification of marine erosion has been observed along the coast of the study area in question, with damages to buildings of the Juréia and Ilha Comprida regions and modifications of the Ilha do Cardoso coastal line (Júnior et al., 2008).

Sea level will continue to rise, reaching values twice as high as the rates recorded in the 20th century, considering rises of 18 to up to 59 $\mathrm{cm}$ in a more pessimistic scenario. Regardless which scenario, sea level will continue to rise at rates between 2 and $3 \mathrm{~mm}$ per year during the first half of the $21^{\text {st }}$ century. The impacts resulting from this sea level rise will be associated with increasing coastal erosion, intrusion of brines in estuaries and coastal aquifers and increase of the flooding risk (Ojeda et al., 1995, Ojeda, 2000, Ojeda \& Villar, 2007, Ojeda et al., 2009, FraileJurado \& Ojeda, 2013).The objectives of this paper were: (i) the cartographic modeling of a possible rise of the mean sea level in the Southern Coast of the State of São Paulo, considering the advance of the highest tide, by applying the Titus and Narayanan, IPCC, Pfeffer and Rahmstorf models; (ii) the preparation of the future scenario for a 2025 land use map; and (iii) crossing of the vulnerability map for a potential sea level rise and the land use and occupation scenario for 2025 for Cananéia-Iguape Estuarine-Lagoonal Complex.

\section{Material and Methods}

\subsection{Study area}

The Cananéia-Iguape Estuarine-Lagoonal Complex is located in the Southern Coast of the State of São Paulo, is limited to the east by the
Atlantic Ocean, and stretches out for $140 \mathrm{~km}$ (Fig. 1). The region encompasses the Cananéia, Iguape and Ilha Comprida municipalities, that together sum $3,414 \mathrm{~km}^{2}$ with a total population of 48,523 inhabitants (Cananéia: 12,226; I guape: 27,270; Ilha Comprida: 9,027), according to the 2010 Censorship performed by the Instituto Brasileiro de Geografia e Estatística (IBGE, 2011).

The study area includes Phanerozoic covers of Neogenic-Quaternary ages, which overlie Ribeira Belt rocks of the Mantiqueira Orogenic System (Hasui, 2012). The Ribeira Belt comprises several domains, the study area being localized in the Coastal Domain.

The Coastal Domain is mostly formed by the Coastal Complex, where the conspicuous geomorphologic feature named Serra do Mar (Mar Ridge) stands out. The Coastal Domain is composed of banded gneisses, granulitic rocks, mica schists, quartzites, and late- to posttectonic granites. The main structural features that occur in the study area are the NE-trending Cubatão Transcurrent Shear Zone (Hasui, 2012), and the Structural-Magnetic Paranapanema Alignment (Ferreira, 1982). The genesis of the Neogenic-Quaternary covers is related to neotectonics processes and to the evolution of the present relief and drainage network (Fig. 2).

Figure 3 shows along the NW-SE-trending section $A$ the Cenozoic graben system, which includes the Ribeira de Iguape Graben where the Cananéia-Iguape Estuarine-Lagoonal Complex is located. This Complex is equivalent to the Cananéia-Iguape Coastal Plain System, defined as one of the environmental systems identified in the Ribeira do Iguape Hydrographic System. This system belongs to an important estuarine region, where mangrove/floodplain ecosystems occur together with plains and marine sand bars, crosscut by fluvial plains (Ross, 2002).

These modern deposits cover the sandy terrains deposited during marine transgression/ regression phases (Cananéia-Santos transgressions). According to Ross (2002), this region is characterized by extremely plain relief, sandy and unconsolidated soils, water table near the surface, and biodiversity richness. It is a unit of great environmental fragility. The geomorphology is characterized by distinct 


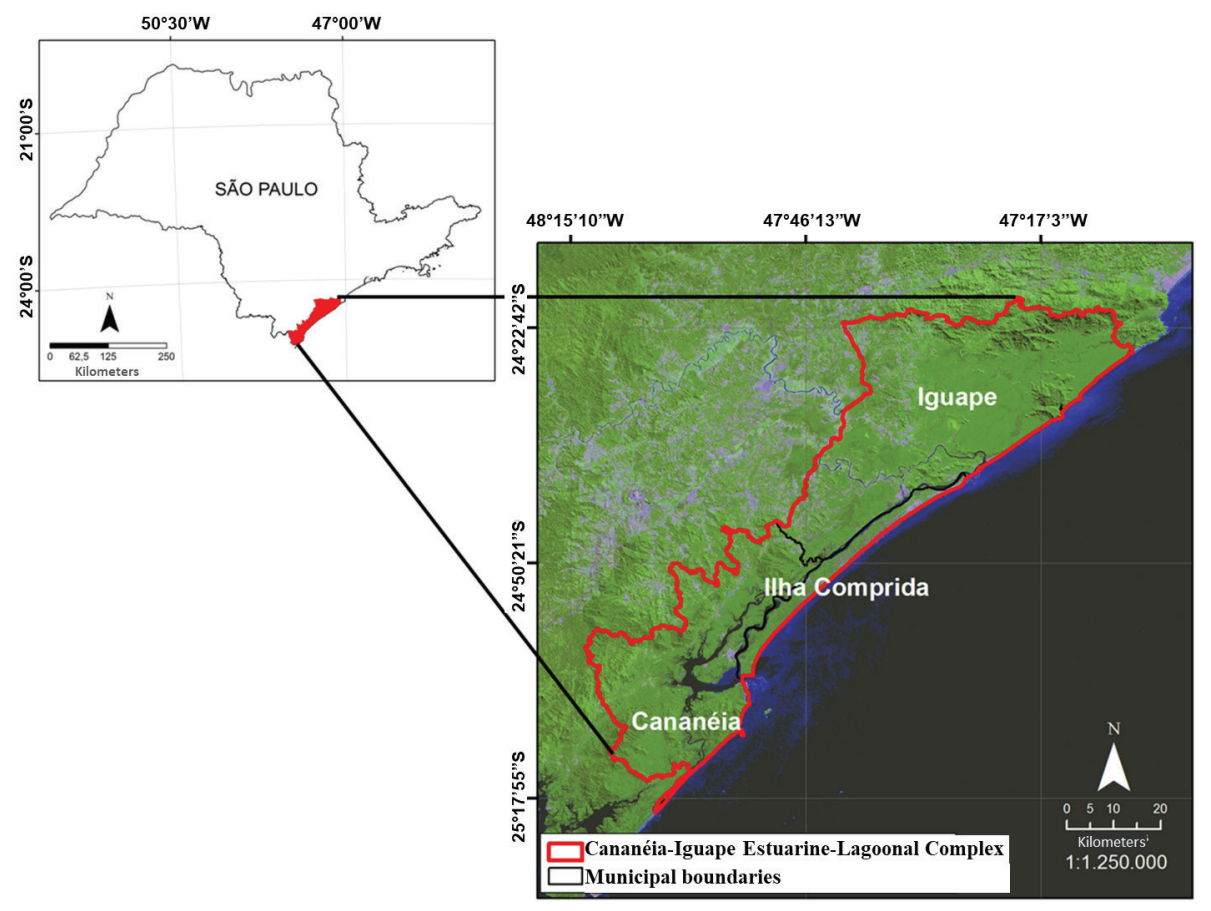

Figure 1. Study area: Cananéia-Iguape Estuarine-Lagoonal Complex (Map reference system - UTM, zone 23S; datum SIRGAS 2000).

Figura 1. Área de estudo: Complexo Estuarino Lagunar Cananéia-Iguape (Sistema de referência - UTM, zona 23S; datum - SIRGAS 2000).

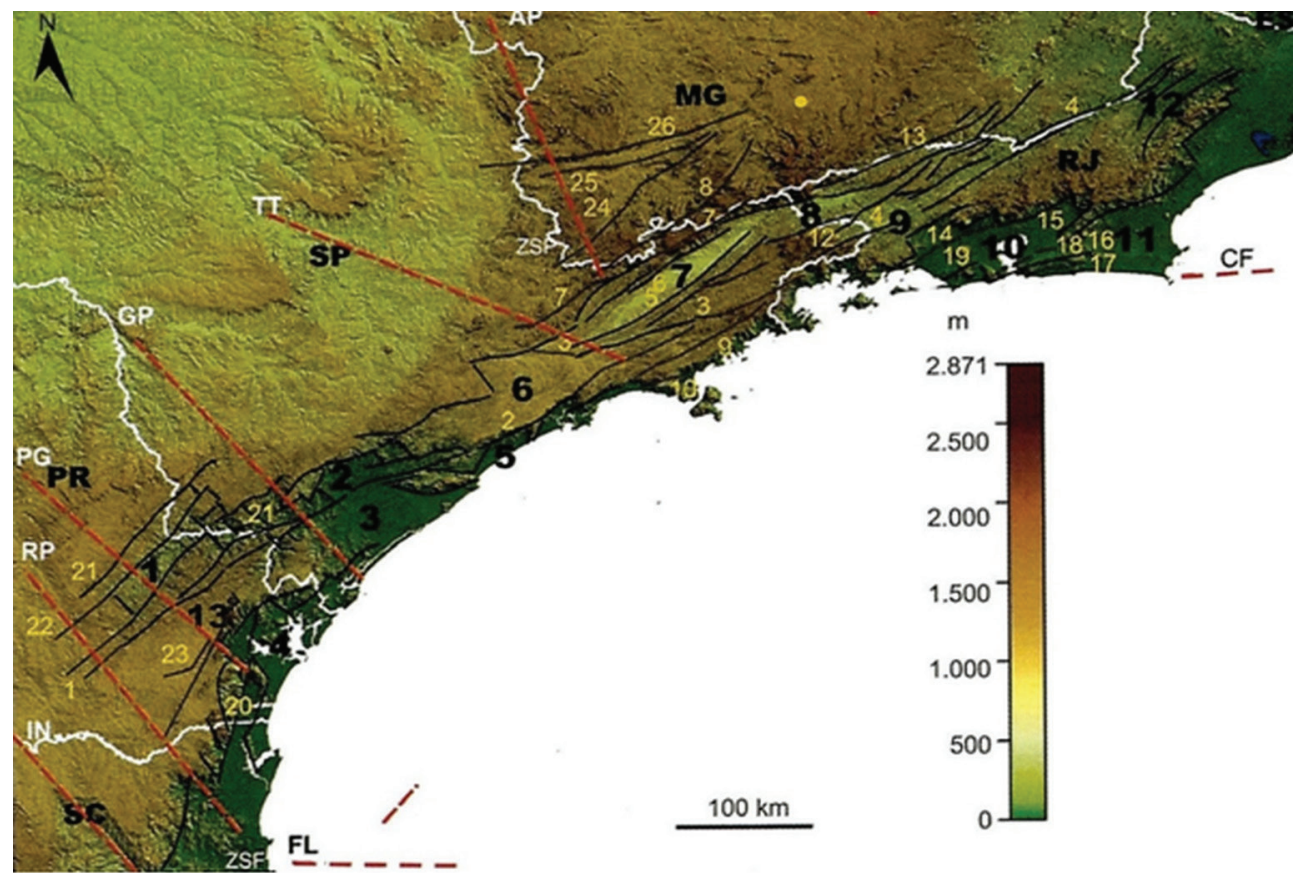

Figure 2. The system of continental rifts in the Southeast. Grábens indicated by black numbers: (1) Alto Ribeira, (2) Sete Barras; (3) Ribeira de Iguape; (4) Paranaguá including the Alexandra, Pariquera-Açu and Guaraqueçaba Formations; (5) Santos; (6) São Paulo; (7) Taubaté; (8) Resende; (9) Volta Redonda; (10) Guanabara; (11) Barra do São João; (12) Baixo Paraíba do Sul; (13) Curitiba. Yellow point: Gráben de Aiuruoca. Source: Gontijo-Pascutti et al. (2012).

Figura 2. O sistema de rifts continentais do Sudeste. Grábens indicados por números em preto: (1) Alto Ribeira; (2) Sete Barras; (3) Ribeira de Iguape; (4) Paranaguá incluindo as formações Alexandra, Pariquera-Açu e Guaraqueçaba;(5) Santos; (6) São Paulo; (7) Taubaté; (8) Resende; (9) Volta Redonda; (10) Guanabara; (11) Barra do São João; (12) Baixo Paraíba do Sul; (13) Curitiba. Ponto amarelo: Gráben de Aiuruoca. Fonte: Gontijo-Pascutti et al. (2012). 


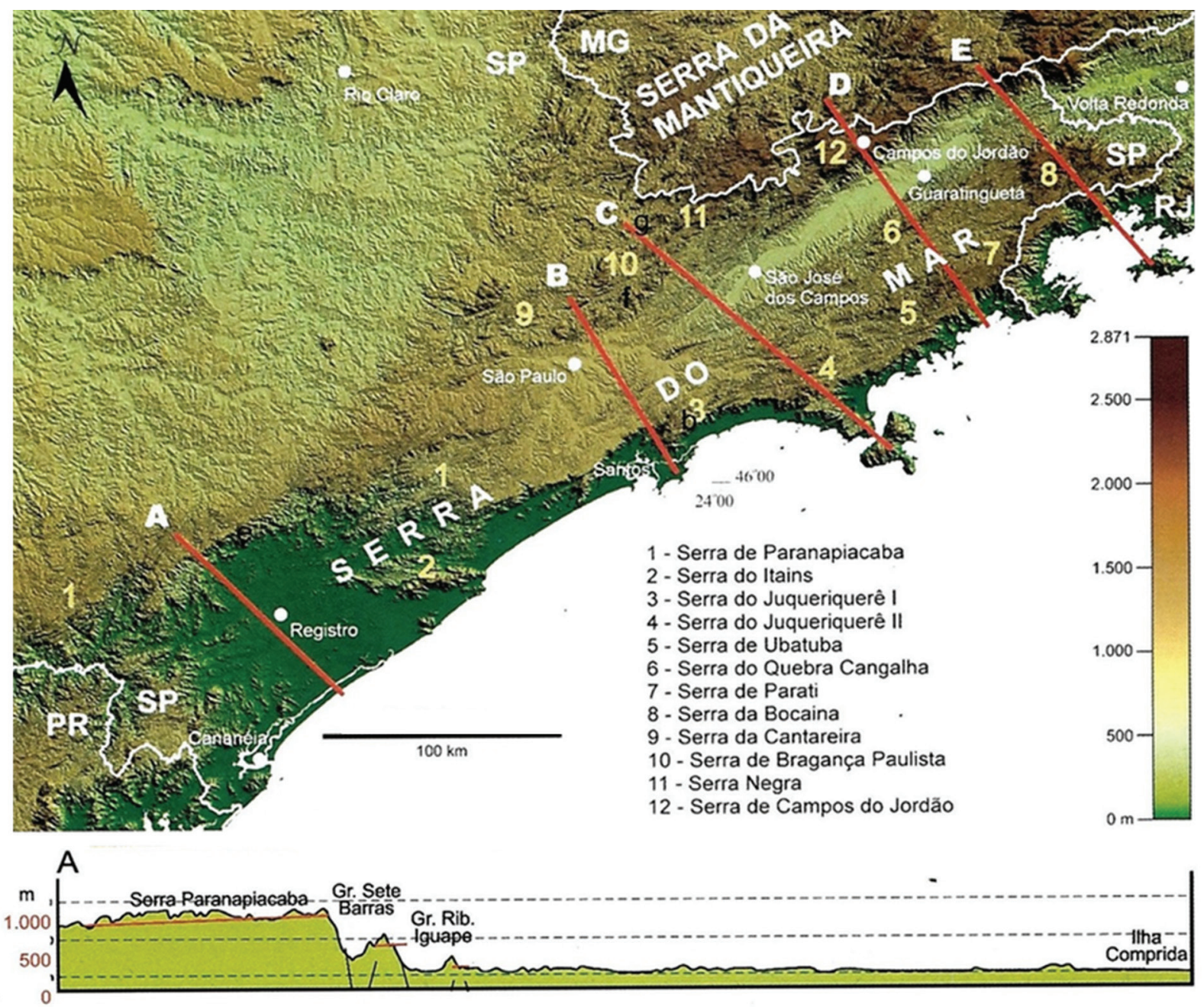

Figure 3. Relief on the Planalto Atlântico Paulista and the differentiation between the south and north segments. In the profiles stands out the great amplitude of the relief and the prominent escarpments of faults of the mountain ranges of the Sea and the Mantiqueira that delimit the cenozoic records stand out. In the sections, the black traces represent the faults that limit compartments between upright blocks and lowered blocks with segments of the dismantled South American Surface in red traces. Source: Gontijo-Pascutti et al. (2012).

Figura 3. Relevo no Planalto Atlântico e a diferenciação entre os segmentos sul e norte. Nos perfis destacam-se a grande amplitude do relevo, as proeminentes escarpas de falhas das serras do Mar e da Mantiqueira que delimitam os grábens cenozoicos. Nas seções, os traços pretos representam as falhas que limitam compartimentos entre blocos soerguidos e rebaixados com segmentos da Superfície Sul-Americana desmantelada (traços vermelhos). Fonte: Gontijo-Pascutti et al. (2012).

tectonic macrocompartments, where relief forms such as ridges, hills, slope and marine and fluvial coastal plains can be recognized (Ross, 2002; Gontijo-Pascutti et al., 2012).

Tectonism represented in section A (Fig. 3) has a direct influence in the geological evolution of the study area, by conditioning the Paranapiacaba Ridge fault escarpment, the origin and sedimentation of the Paleogene Sete Barras and Ribeira de Iguape grabens, and the PariqueraAçu Formation Neogenic deposits (Melo, 1990; Ross, 2002; Gontijo-Pascutti et al., 2012). The Paranapiacaba Ridge escarpment is controlled by the reactivation of the Cubatão Fault. Its extreme straightness associated with a steep profile showing a despicable dissection degree are elements that suggest tectonic reactivation in the Quaternary, because there has not been time enough to accelerate erosion.

The Cananéia-Iguape Estuarine-Lagoonal Complex is the most preserved unit of the Southern Coast of the State of São Paulo. Besides the temporary occupation during summertime and as second residence, along the margins of the Cananéia and Ilha Comprida, villages of traditional riverside populations, mostly dedicated to fishing, have developed (Ross, 2002). 


\subsection{Simulation of the land use in the Cananéia- Iguape Estuarine-Lagoonal Complex}

The methodology here described was used in the assessment of the evolution of the relationship between type and intensity of the land use and occupation classes (1986, 1999 and 2010), and to predict the scenario of the distribution of land use and occupation classes in 2025. This simulation was carried out by means of the Markov chain methods (Gordon, 1965) and calibration of the simulation model and Markov chains, coupled with a cellular automaton algorithm of the IDRISI Andes program (Eastman, 2006), based on Valente \& Vettorazzi (2008) and Terra (2010).

To simulate land use and occupation in 2010, maps from 1986/1987 and 1999 were used, generated by the automated classification process. The landscape modifying agents and their respective driving causes used in this simulation process were: Slope; Influence of the road network; Influence of farming areas; Formation of residential nuclei; Susceptibility to erosion; Susceptibility to mass movements, and Dense arboreal vegetation, playing the role of a landscape restrictive agent.

The calibration of the model was performed by simulating year 2010 from land use and occupation maps from 1986 and 1999. The aim of this calibration was to establish how accurate the model is by comparing the simulated map for 2010 with the land use and occupation map of 2010, which resulted from the supervised classification (Jensen, 2011) of the TM sensor scenes (Landsat 5).

The land use and occupation maps of 1986 and 1999 (raster format, 30-m spatial resolution) were used as input data in the Markov module. The output files of this module were a transition probability matrix, which represents the probability of each pixel of each land use and occupation class to be changed to another category, and a group of conditional probability images, which represent the probabilities of each pixel to be in each of the land use and occupation categories in the future. This calibration was performed in the Markov module of the IDRISI Andes program (Eastman, 2006), as shown in Figure 4

A map was prepared for each modifying agent of the chosen landscape by means of several tests, using different types of functions and control points in the Idrisi fuzzy module, which converts the factors both to a real-number scale (zero and one) and a bytes scale (zero and 255). The latter option is recommended for Idrisi because the Multi-Criteria Evaluation (MCE) module was designed for faster processing in bytes (Eastman, 2006).

\section{CALIBRATION OF THE MODEL}

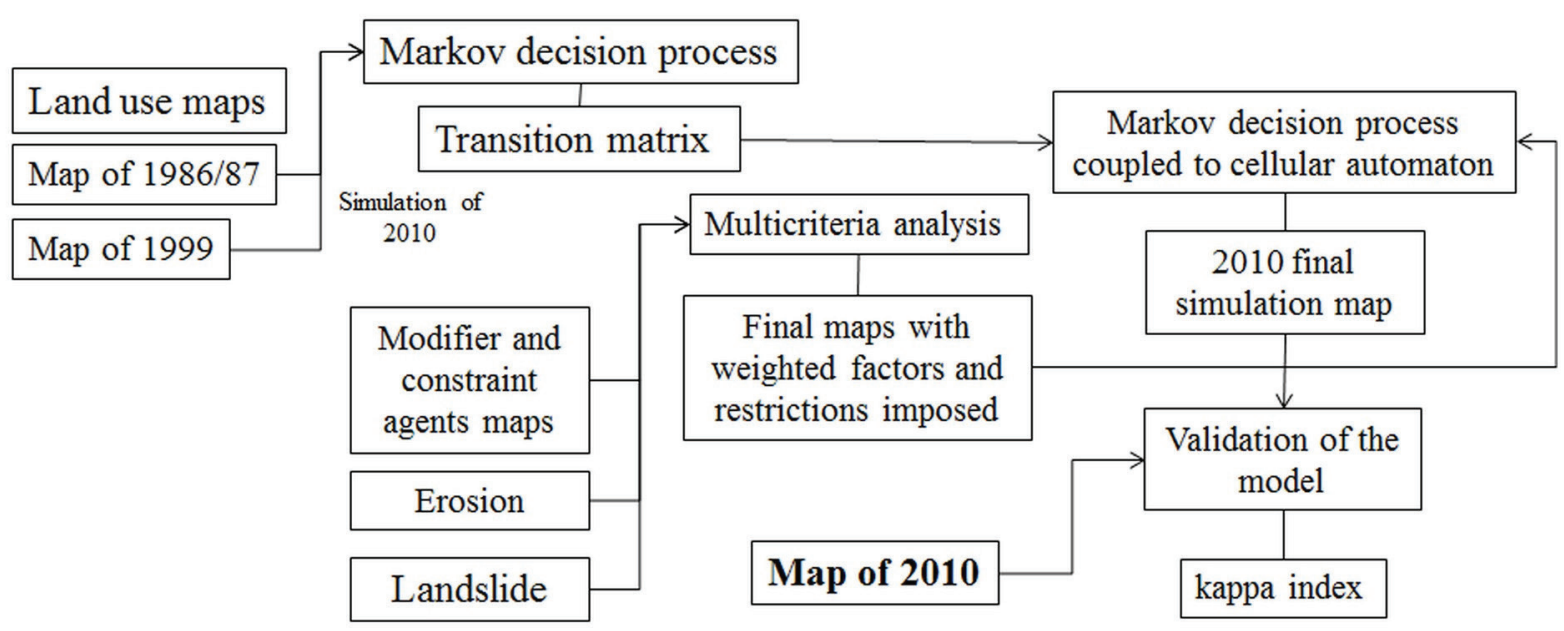

Figure 4. Representation of the model calibration method, based on Terra (2010).

Figura 4. Representação do modelo do método de calibração. Baseado em Terra (2010). 
The sigmoidal function was chosen because this type of function does not have extreme points, but inflection points, in which the minimum or maximum rates of function variation occur (Florentino et al., 2010). Funahashi (1989) argued that the sigmoid function is able to approximate continuous functions at a predetermined interval with precision, and these are the situations that will be described next, where different factors used in the multi-criteria evaluation were not comparable because showed different types of units. Thus, all factors (maps) were transformed to a byte scale with sigmoidal function, respecting the maximum and minimum values for each factor, as found in the specialized bibliography.

The slope map was prepared from contour lines extracted from 1:50,000-scale topographic charts. The first step was to prepare a digital terrain model (DTM) using ArcGIS 10 (ESRI, 2010). In IDRISI this DTM was input into the "Surface" module, thus producing a slope map in percentage. The slope map was reclassified in the "Reclass" module to a zero-to-255 scale. The intervals used were established according to Ramalho Filho \& Beek (1995). These intervals are listed in Chart 1.

\subsubsection{Influence of access roads}

The Idrisi Reclass module was used to prepare a Boolean image, where the access roads receive a unit value (1) and the other classes a null value (0). This image was inserted in the module Distance for the preparation of a distance map from the lines that represent the road network. The output images of the module "Distance" were inserted on the module Fuzzy, where a decreasing sigmoid function was established. The control point values are: $a=100 \mathrm{~m}$ and $\mathrm{b}=200 \mathrm{~m}$.

\subsubsection{Influence of the farming areas}

Similarly to the procedure adopted to the road network, the areas of banana farming were reclassified with a unit value (1) and the other classes with a null value (0). The module Distance was executed and the output map was rescheduled in the module Fuzzy, where a decreasing sigmoid function was established.
The control point values are: $\mathrm{a}=1000 \mathrm{~m}$ and $\mathrm{b}=$ $1500 \mathrm{~m}$.

\subsubsection{Formation of urban nuclei}

The urban areas were reclassified with a unit value (1) and the other classes with a null value (0) The module Distance was executed and the output map was rescheduled in the module Fuzzy, where a decreasing sigmoid function was established. The control point values are: $\mathrm{a}=50$ $\mathrm{m}$ and $\mathrm{b}=100 \mathrm{~m}$.

\subsubsection{Areas susceptible to mass movements or erosion}

The maps of susceptibility to mass movements or erosion prepared by Dalmas et al. (2015) were used as modifying agent. In module Fuzzy the areas of lowest susceptibility to both events were set to the highest aptitude value (255), whereas areas of highest susceptibility were set to zero.

\subsubsection{Dense arboreal vegetation as restriction area}

A dense arboreal vegetation map was prepared for 1999 to serve as a restrictive agent to the areal expansion of land use classes, linked to anthropic action.

\subsubsection{Preparation of each land use class for multi-criteria evaluation}

Individual maps representing each land use and occupation class of the Cananéia-Iguape Estuarine-Lagoonal Complex were prepared for the multi-criteria evaluations. The classes and the applied method used to prepare each map are listed in Chart 2.

\subsubsection{Attribution of weights to the modifying agents}

Maps of each land use and occupation class were input into the IDRISI Cellular Automata module, resulting in the final map that simulated the future scenario. These maps of land use 
Chart 1. Slope, values and adequacy-of-use classes intervals (source: Ramalho Filho \& Beek, 1995). Quadro 1. Declividade, valores e intervalos de adequação das classes (fonte: Ramalho Filho \& Beek, 1995).

\begin{tabular}{|c|c|c|}
\hline Slope classes (in degrees) & Adequacy values & Adequacy classes \\
\hline 0 to $13 \%$ & 255 & High \\
\hline 13 to $20 \%$ & 170 & Medium \\
\hline 20 to $45 \%$ & 85 & Low \\
\hline 45 to $100 \%$ & 0 & Restrict \\
\hline
\end{tabular}

Chart 2. Land use and occupation classes participating in the multi-criteria evaluation. Quadro 2. Classes de uso e ocupação do solo participantes da avaliação multicritérios.

\begin{tabular}{|c|c|c|c|}
\hline \multirow{2}{*}{ Factor } & \multirow{2}{*}{ Function } & \multicolumn{2}{|c|}{ Control points (meters) } \\
\hline & & a & b \\
\hline Banana farming & Decreasing sigmoid fuzzy & 1000 & 1500 \\
\hline Hydrography & Decreasing sigmoid fuzzy & 250 & 500 \\
\hline Dense arboreal vegetation & Decreasing sigmoid fuzzy & 1000 & 2000 \\
\hline Floodplain or campo sujo vegetation & Decreasing sigmoid fuzzy & 0 & 10 \\
\hline Exposed soil & Decreasing sigmoid fuzzy & 0 & 10 \\
\hline
\end{tabular}

classes result from a multi-criteria evaluation (Weighted Linear Combination - WLC), where the modifying agents were firstly multiplied by their weight. After that, the results for all agents were added. The restrictive agents are applied in the analysis to make the excluded areas null. The weights attributed to the modifying agents in WLC are very important because they determine how the modifying agents (factors) will compensate one another. In this case, the higher the factor weight, the higher its influence in the final map (Eastman, 2006).

The process of weighting the factors involved in WLC was carried out using the Principal Components technique. This technique is a multivariate statistics method used to analyze a dataset aiming at data reduction, elimination of overlaps and assigning the most representative weights (loadings) of these data from their linear combination (Jolliffe, 2002). Thus, the calculation of the weights of the landscape modifying agents was performed using the IDRISI Principal Components Analysis module (Eastman, 2006).
A different combination of agents was used for each land use and occupation map in order to find out the values that were later used in WLC, as seen in the tables relative to the maps of land use classes (Chart 3).

\subsubsection{Preparation of the final map with the overlapping of modifying agents}

By applying the IDRISI multi-criteria analysis, the modifying agents were overlapped for the preparation of maps for each land use and occupation class (resulting from the supervised classification process). After the Principal Components weighting, these agents were incorporated as factors in the weighted linear combination process, where they were clustered and multiplied by the respective weights. Thus, maps for each land use and occupation class were prepared, where each pixel represents the probabilities of each pixel changing or not to another category in the stipulated time.

It was observed that the areas of classes 
Chart 3. Principal components and modifying agents.

Quadro 3. Principais componentes e agentes modificadores.

\begin{tabular}{|c|c|c|}
\hline Principal Components & Modifying agent & Value \\
\hline \multirow{3}{*}{ Urban area } & Urban area & 0.0004 \\
\hline & Slope & 0.0002 \\
\hline & Road network & 0.9994 \\
\hline \multirow{3}{*}{ Hydrography } & Hydrography & 0.0015 \\
\hline & Banana farming & 0.0002 \\
\hline & Slope & 0.9983 \\
\hline \multirow{2}{*}{ Banana farming } & Slope & 0.0002 \\
\hline & Road network & 0.9997 \\
\hline \multirow{2}{*}{ Dense arboreal vegetation } & Dense arboreal vegetation & 0.8271 \\
\hline & Floodplain or campo sujo vegetation & 0.1729 \\
\hline \multirow{3}{*}{ Floodplain or campo sujo vegetation } & Floodplain or campo sujo vegetation & 0.1096 \\
\hline & Hydrography & 0.0014 \\
\hline & Slope & 0.889 \\
\hline \multirow{5}{*}{ Exposed soil } & Exposed soil & 0.03185 \\
\hline & Slope & 0.84748 \\
\hline & Areas susceptible to erosion & 0.11654 \\
\hline & Urban area & 0.00407 \\
\hline & Road network & 0.00006 \\
\hline
\end{tabular}

"floodplain or campo sujo vegetation" and "exposed soil" were reduced between 1999 and 2010. However, in the simulations carried out in the cellular automata, where the results also point to reduction of these areas, this reduction is less than that shown in the real map, reaching extremes of areas 150\% larger than the real map for these classes. Thus, the system was 'forced' to reduce these areas during the simulation by means of a filter in the weighted linear combination process, where the "floodplain or campo sujo vegetation" and "exposed soil" classes could not expand their areas over those of the other classes. This filter was designed using a mask where the "urban area", "hydrography", "banana farming" and "dense arboreal vegetation" classes were set to zero.

\subsubsection{Simulation of the scenario that represents the 2010 land use and occupation classes}

The maps of land use and occupation classes generated from the multi-criteria analysis were input into the cellular automata module coupled with the Markov chains with the matrix for transition areas and maps of probabilities. The module was informed that the interaction would be of eleven times for an 11-year future scenario. The cellular automaton filter Standard $5 \times 5$ contiguity was selected. The result of this process is the simulated scenario map with the distribution of land use and occupation classes in 2010. This map was compared to another map resulting from the supervised classification for the same year. The comparison between the real and 
the simulated maps of land use and occupation classes for 2010 showed that the greatest differences were in the "floodplain or campo sujo vegetation" and "exposed soil" classes, which in the simulation increased respectively $33 \%$ and $25 \%$ in relation to the real map.

Both images resulting from classification and simulation were compared by means of the kappa concordance index (Cohen, 1960), IDRISI Andes Crosstab module (Eastman, 2006). Approximately 400 hours were spent in processing, including several types of simulations and changes of control points within the Fuzzy module for all maps. Thus, processing reached a similarity index of 0.4133 , which, according to Landis \& Kochsource (1977), is a moderate value. Considering the size and heterogeneity of the study area, this value is not ideal, but satisfactory.

In order to evaluate the classification of the land use and occupation scenario map of 2010, in addition to the Kappa Index, a trip to the study area (08/06/2012 and 08/07/2012) was also carried out to record points of control to later validate model. In this trip 20 control points were recorded, representing 4 points per each land use and occupation class. The accuracy rate between what was visualized in the study area and the 2010 scenario map was $95 \%$.

\subsubsection{Simulation of the scenario that represents the 2025 land use and occupation classes}

The methodology applied to simulate the 2010 scenario was replicated to the 15-year interval, based on the 2010 map. Thus, the 1999 and 2010 land use and occupation maps were input into the Markov module. Six maps resulting from the combination of factors and restrictions regarding 2010 were input into the multi-criteria evaluation. The result is the 2025 scenario (Fig. 5).

\subsection{Calculation of the potential sea level rise}

\subsection{Preparation of the digital terrain model}

The first step of the methodology was to prepare a digital terrain model (DTM), on which mean sea water level rise scenarios were overlain, using the 3D Analystextension of ArcGISversion 10 (ESRI, 2010). The DTM was prepared with a 10-m spatial resolution, using the following database: elevation points extracted from 1:10,000-scale topographic charts; contour lines extracted from 1:10,000-scale topographic charts; contour lines extracted from 1:50,000-scale topographic charts; and vectorized coast line on a scene from the SPOT sensor (2011), with elevation attribution of $1 \mathrm{~m}$.

\subsubsection{Calculation of the local trend of the mean sea water level variation using Cananéia tide gauge data}

A long series of records from the Cananéia tide gauge (1954-2006) was used to calculate the local mean sea level variation rate. These records were taken from the Permanent Service for Mean Sea Level - PMSL (PMSL, 2017). According to Fraile-Jurado (2011), there are different methodologies to calculate the variation trend in sea level series from a tide gauge, such as: linear regression, harmonic decomposition, and application of empirical orthogonal functions. In his research, Fraile-Jurado compared the three techniques and chose linear regression because it is less sensitive to the lack of records in tide gauges in his study area (Andalusia, Spain), during some years within the historic series of his interest. Similarly, the records relative to 2005 are missing in the Cananéia tide gauge and therefore we chose to use linear regression.

The result obtained for 52 years of recording with the Cananéia tide gauge is an annual mean sea level rise of $4.21 \mathrm{~mm}$. This rate is much higher than the global mean of $1.7 \mathrm{~mm}$ $( \pm 0.5 \mathrm{~mm}$ ) relative to the 20th century (IPCC, 2010). Therefore, the value $2.51 \mathrm{~mm}$ represents the local factor, which is the difference between the local rate and the global mean recorded for the 20th century. The product of the application of linear regression is a first-degree equation $(Y=A+B X)$, where coefficient $B$ represents the annual variation rate of the tide gauge data series (Kendall \& Ord, 1990). The graph that represents the calculated linear regression line is shown in Figure 6. 


\section{SIMULATION OF LAND USE CLASSES OF 2025}

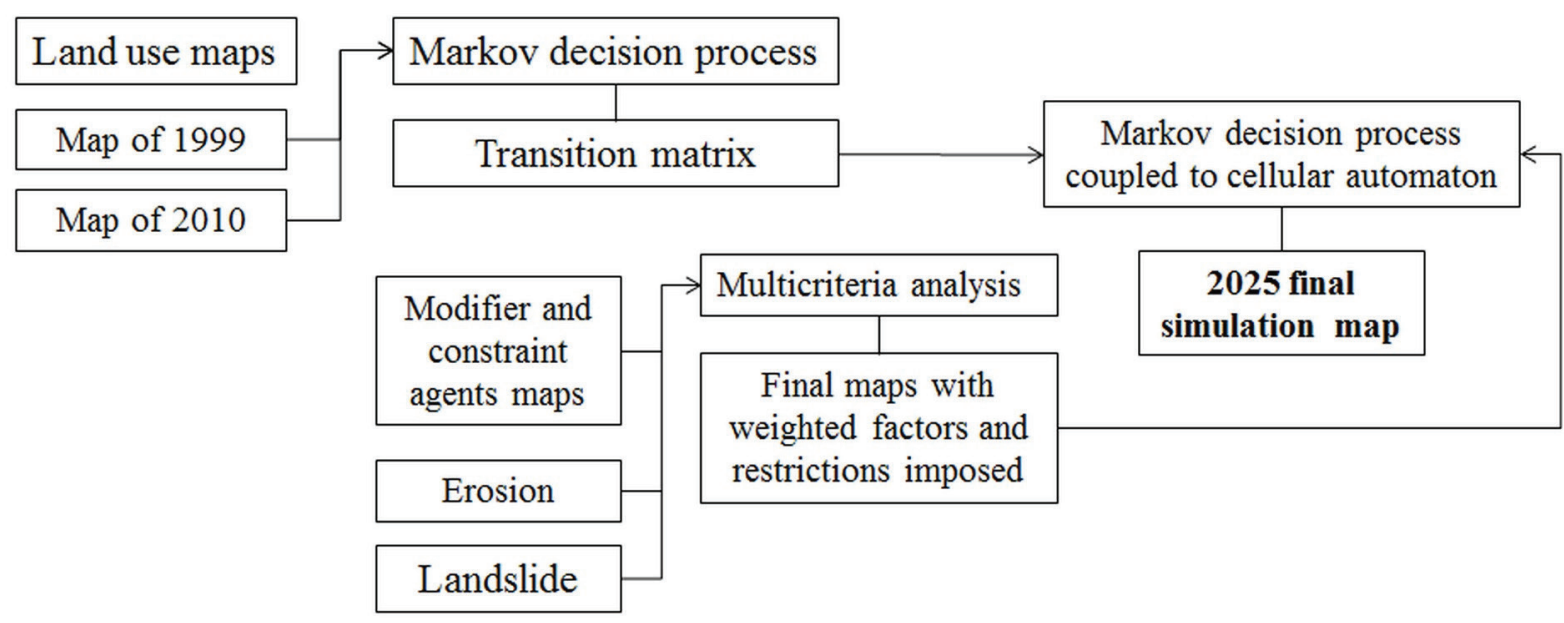

Figure 5. Representation of the land use and occupation simulation method for 2025 (based on Terra, 2010).

Figura 5. Representação do método de simulação do uso e ocupação do solo em 2025 (baseado em Terra, 2010)

\subsubsection{Highest tide value}

According to the Cananéia tide gauge data, available on the electronic page TIDE FOR FISHING (Tide for Fishing, 2017), the highest tide recorded was $1.3 \mathrm{~m}$ and the minimum height of $-0.1 \mathrm{~m}$. Therefore, in all models applied in this study the maximum value of $1.3 \mathrm{~m}$ was considered as the highest tide.

\subsubsection{The Titus and Narayanan's model}

By applying the Titus and Narayanan's model and by means of the relationship between global and local variables, we could estimate the mean sea level variations for a certain date, based on a tide gauge dataset. With this model it is possible to calculate a potential sea level rise, considering the local mean sea level and the acceleration of the mean sea level rise during the 21 st century. This model considers that the mean sea level results from the thermal expansion and conditions established by different climatic models generated by IPCC and calving of small ice plates.

Titus \& Narayanan (1995) assume that the rise of the mean sea level is composed of global and local components. The global component results from the emission of greenhouse gases, from which and by means of equations one can obtain the resultant radioactive forcing that triggers ocean circulation and consequently an increase in the temperature of oceanic waters. Two consequences can derive from this increase in ocean temperature: water thermal expansion and ice plate calving. The thermal expansion is the main conditioning factor of mean sea level rise. The second or local component is based on the relationship between the global component and the local variation rates of the mean sea level. The Titus and Narayanan's model can correlate the local records of a local tide gauge with those of global projections of sea level rise.

The global mean ocean level rise, in any tide gauge of the planet, was $1.2 \mathrm{~mm} /$ year throughout the 20th century (Titus \& Narayanan, 1995). A different growth rate, recorded in any tide gauge of the planet, is explained by the existence of local factors. In most of the mean sea level change scenarios, an acceleration of the sea level rise rates is expected, according to the rates recorded in the 20th century. For Titus \& Narayanan (1995), when combining the local rates recorded in each tide gauge with the future sea level change expectations, it is necessary to observe that during the 20th century there were global factors, apparently related to climatic changes, that can vary during the decades to come. However, these authors assume that the local factors will not vary in the following years, because these factors present a much wider time scale (Fraile-Jurado, 2011). 


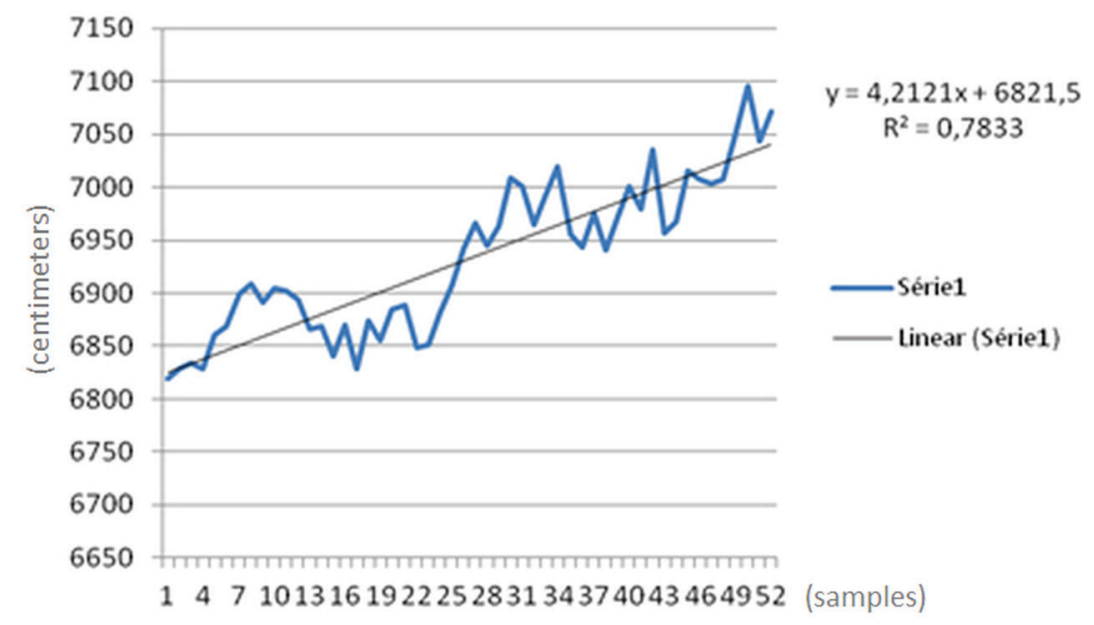

Figure 6. Linear regression analysis of the 1954-2006 Cananéia tide gauge records. Figura 6. Análise de regressão linear dos registros do marégrafo de Cananéia, entre 1954 e 2006.

Therefore, once the local sea level change rates are acquired, it is enough to know the predicted value for the local sea level rise or fall in the future, considering the value recorded during the 20th century (1.2 mm/year). The Titus and Narayanan's model is a normalized model used to avoid considering twice the contribution of the 20th century global factors, once the local factors already consider the global influence (FraileJurado et al., 2014). In this model it is enough to include the value of the Local trend in Equation 1:

Local $(t)=$ Normalized $T+(t-1990) \times$ Local trend $($ Eq. 1)

Where: Local (t) is the future local scenario at moment " $\mathrm{t}$ ", based on global expectations of the sea level change; Normalized $\mathrm{T}$ is the scenario of the model normalized to moment " $\mathrm{t}$ ", from which the 20th century global component has already been eliminated; " $t$ " is the year for which the expectation is being calculated; Local trend is the linear rate recorded in the tide gauge.

\subsubsection{Pfeffer's Model}

Pfeffer et al. (2008) using climate modeling and on the basis of past records, proposed a sea level rise model for the end of the 21 st century, taking into account the contribution of calving of the polar ice caps. In their study glaciological conditions were considered to estimate the sea level in 2100. The authors concluded that increases of more than two meters are physically untenable. This increase could be reached in a scenario in which all the variables involved would be quickly accelerated to extremely high limits. The best possibility is an increase of $0.8 \mathrm{~m}$ by 2100.

The method designed by Pfeffer et al. (2007) is based on projections of ice calving and discharge in the ocean, in which this process was accelerated at different velocities that, according to the authors, have direct influence in the rise of the mean sea level. To obtain a global estimate of the future sea level, the authors considered the rise projected by IPCC (2007). Three scenarios combine probable projections. Scenario 1 represents a small sea level rise, the projection being designed using specific adjustments in the polar areas potentially vulnerable to calving. The calving velocities of the Greenland and Pine Island glaciers were doubled in relation to present rates and no alteration was considered regarding the Lambert/Amery region. Thus, in Scenario 1 the result is a mean sea level rise of $785 \mathrm{~mm}$ in 2100.

To create Scenario 2, the authors estimated the contribution from Greenland as calculated for Low 1, but reduced the influence of ice calving in Antarctica. However, the total contribution of the calving of glaciers and ice caps triggers a higher sea level rise in Scenario 2, so that the net result, including thermal expansion, is an $833 \mathrm{~mm}$ rise in 2100 . 
Scenario 3 combines the influence of Greenland, Antarctica, glaciers and caps, but projecting high acceleration values for calving for all these areas. The net result, including thermal expansion for Scenario 3 is $2008 \mathrm{~mm}$ in 2100 (Pfeffer et al., 2008). We use Pfeffer's values (Scenarios 1, 2 and 3) as global and the local influence was added as shown in Equation 2.

Local $(2100)=$ Pfeffer's Scenario + [local factor $\times(2100-$ 1990)] (Eq. 2)

Where: Local (2100) is the local scenario projected to 2100; in Pfeffer's model, the following values were considered: $78.5 \mathrm{~cm}$ for Scenario 1, $83.3 \mathrm{~cm}$ for Scenario 2 and $200.8 \mathrm{~cm}$ for Scenario 3; Local factor is the local linear rate recorded in the tide gauge, which results from the subtraction of Total Local Rate from Global Factor; 1990 is the base year of the analysis. The result of the equation is then added to the mean sea level in Cananéia, recorded in the local tide gauge.

\subsubsection{Rahmstorf's Model}

Rahmstorf (2006) mentions that the present models based on physical data are very limited to calculate future changes in the mean ocean levels as consequence of certain scenarios of the Earth's surface warming; moreover, these models are not adequate to totally reproduce the mean ocean level rise in the last decades. Differently from the behavior of the models based on physical data, the semi-empirical models can be an alternative to estimate the response of the sea level in face of the Earth's surface warming.

Therefore, Rahmstorf presents the results of a semi-empirical relationship between the mean sea level rise with the Earth's surface mean temperature and proposes that such relationship is direct, so that during the 20th century there was an increase of $3.4 \mathrm{~mm} /$ year per Celsius degree. In parallel, he applied these results to future warming scenarios by IPCC (2007) and obtained the global mean sea level rise for 2100 between 0.5 to 1.4 meters above the 1990 mean level. Following Rahmstorf's (2006) considerations, we applied two equations to model the global rise of $0.5 \mathrm{~m}$ or $1.4 \mathrm{~m}$ for 2100 (Eq. 3):
Local $(2100 z)=Z+[$ Local factor $\times(2100-1990)](E q .3)$

Where: Local (2100) is the local scenario projected to 2100 for scenarios calculated using the Rahmstorf's method; $Z$ is Rahmstorf's global rise to be used in the equation (50 or $140 \mathrm{~cm}$ ); Local factor is the linear local rate recorded in the tide gauge $(2.51 \mathrm{~mm})$.

\subsubsection{Intergovernmental Panel on Climate Change (IPCC) Model}

In the last report published by the Intergovernmental Panel on Climate Change - Working Group I: The Physical Science Basis (IPCC, 2007) it was predicted that the mean sea level will rise between 0.18-0.38 m (Scenario B1), 0.20-0.43 m (Scenario B2), 0.21-0.48 m (Scenario A1B), 0.20-0.45 m (Scenario A1T), 0.20-0.51 m (Scenario A2), and 0.26-0.59 m (Scenario A1F1) by the end of the 21st century. In all scenarios for the 21 st century the mean rise rate exceeds the rate recorded between 1961-2003 (1.8 mm/ year, varying plus or minus $0.5 \mathrm{~mm}$ ). According to Scenario A1B, between 2090 and 2099 the estimate is a rise of $3.8 \mathrm{~mm} /$ year. In relation to the data published in the IPCC report, in a moderate model, the sea level rise scenario is of only $2 \mathrm{~cm}$ for 2050 and $15 \mathrm{~cm}$ for the end of the century.

For all IPCC scenarios, thermal expansion has the largest influence in sea level rise, contributing between 70 to $75 \%$ of the total value. It is mentioned in this report that some models indicate the Antarctica ice cap will increase, gaining mass, which will negatively contribute to sea level rise. The acceleration of ice formation observed in some Greenland glaciers and in some Antarctica brooks can substantially increase the formation of glaciers. The report concludes that the sea level rise during the 21st century is predicted to vary geographically. The scenario models are not the same, but present some characteristics in common, for example, lower increase of the mean sea level in the Antarctic Ocean, a higher increase in the Artic, and increase throughout the South Atlantic and Indian oceans (IPCC, 2007). The methodology here applied adopts a series that includes the minimum value 
of sea level rise predicted for Scenario B1 and the maximum value of Scenario AIFI. Therefore, we used the variation $0.18-0.59 \mathrm{~m}$ as global rise for 2100, as shown in Equation 4.

$$
\text { Local }(21000.18)=18+[\text { Local factor } \times(2100-1990)]
$$

Where: Local (2100) is the local scenario projected for 2100 for scenarios calculated using the IPCC method; $Z$ is the global IPCC increase to be used in the equation (18 or $59 \mathrm{~cm}$ ); Local factor is the linear local rate recorded in the tide gauge $(2.51 \mathrm{~mm})$.

\section{Results}

\subsection{Potential sea level rise modeling}

The maximum sea level values for the southern coast of the State of São Paulo are presented for each of the methods previously described. The Cananéia highest tide value of 1.3 $\mathrm{m}$ was considered in all equations.

\subsubsection{Application of the Titus and Narayanan's model}

The Titus and Narayanan's equation (Eq 1) was applied to years 2025, 2050 and 2100, using $0.42 \mathrm{~cm}$ as the Local trend and $1.72 \mathrm{~m}$ as the mean sea level in Cananéia in 1990 and considering in the calculations probabilities of $99 \%, 50 \%$ and $1 \%$ of such event to occur. As the reference year is 1990, in field "t" of equation 1 the following values were used: 35 to calculate the mean sea level for year 2025; 60 to calculate the mean sea level for year 2050, and 110 to calculate the mean sea level for year 2100 . The results are listed in table 1.

Table 1. Results (in $\mathrm{cm}$ ) obtained from the application of the Titus and Narayanan's equation for years 2025, 2050 and 2100 .

Tabela 1. Resultados (cm) obtidos através da aplicação da equação de Titus e Narayanan para os anos de 2025, 2050 e 2100 .

\begin{tabular}{cccc}
\hline Probability (\%) & $\mathbf{2 0 2 5}$ & $\mathbf{2 0 5 0}$ & $\mathbf{2 1 0 0}$ \\
\hline 99 & 4.7 & 9.2 & 22.2 \\
50 & 19.7 & 35.2 & 71.2 \\
1 & 33.7 & 60.2 & 138.2 \\
\hline
\end{tabular}

The mean sea level in Cananéia in the reference year 1990, calculated as $172 \mathrm{~cm}$, was added to the values listed in table 3 , as shown in table 2. The value relative to the highest tide was added to these values, as shown in table 3.

The Titus and Narayanan's model enables modeling of the mean sea level in the user's time horizon of interest, considering the probabilities. Fraile-Jurado (2011) mentions that the majority of the maps presented in different studies were calculated using a $50 \%$ probability, that is, there is the $50 \%$ probability that the sea level of the model be exceeded in " $\mathrm{t}$ " years.

For this modeling of the future mean sea level in the southern coast of the State of São Paulo, 99\%, 50\% and 1\% probabilities were chosen, the latter being the most improbable, implying the highest levels. The years chosen for modeling were 2025, 2050 and 2100, and the respective flooded areas are presented in table 4.

Table 2. Results from adding the values obtained from the application of Titus and Narayanan's equation to the mean sea level value in Cananéia (1990) for 2025, 2050 and 2100 (cm).

Tabela 2. Resultado da adição dos valores obtidos da aplicação da equação de Titus e Narayanan ao valor médio do nível do mar em Cananéia (1990) para 2025, 2050 e $2100(\mathrm{~cm})$.

\begin{tabular}{cccc}
\hline Probability (\%) & $\mathbf{2 0 2 5}$ & $\mathbf{2 0 5 0}$ & $\mathbf{2 1 0 0}$ \\
\hline 99 & 177.6 & 182.1 & 195.1 \\
50 & 192.6 & 208.1 & 244.1 \\
1 & 206.6 & 233.1 & 311.1 \\
\hline
\end{tabular}

Table 3. Results from adding the values Table 2 to the highest tide $(130 \mathrm{~cm})$ for 2025, 2050 and $2100(\mathrm{~cm})$.

Tabela 3. Resultados da adição dos valores da Tabela 2 ao valor da mais alta maré $(130 \mathrm{~cm})$ para os anos 2025, 2050 e $2100(\mathrm{~cm})$.

\begin{tabular}{cccc}
\hline Probability (\%) & $\mathbf{2 0 2 5}$ & $\mathbf{2 0 5 0}$ & $\mathbf{2 1 0 0}$ \\
\hline 99 & 307.6 & 312.1 & 325.1 \\
50 & 322.6 & 338.1 & 374.1 \\
1 & 336.6 & 363.1 & 441.1 \\
\hline
\end{tabular}

Table 4. Areas flooded by the highest tide for 2025, 2050 and $2100\left(\mathrm{~km}^{2}\right)$.

Tabela 4. Áreas inundadas pela maré mais alta nos anos de 2025, 2050 e $2100\left(\mathrm{~km}^{2}\right)$.

\begin{tabular}{cccc}
\hline Probability (\%) & $\mathbf{2 0 2 5}$ & $\mathbf{2 0 5 0}$ & $\mathbf{2 1 0 0}$ \\
\hline 99 & 453 & 459 & 474 \\
50 & 472 & 488 & 522 \\
1 & 487 & 512 & 581 \\
\hline
\end{tabular}




\subsubsection{Titus and Narayanan's maps}

In this item the maps prepared for 2025 (Fig 7), 2050 (Fig. 8) and 2100 (Fig. 9) are presented, considering the probabilities of $1 \%, 50 \%$ and $99 \%$.

\subsubsection{Pfeffer's model}

Pfeffer equation (Eq. 2) was applied using the value $0.25 \mathrm{~cm}$ as Local trend. The products of this equation were added to the mean sea level recorded in the Cananéia tide gauge in 1990 (1.72 $\mathrm{m})$. The results of the application of Equation 2 can be seen in Table 5. As the reference year is 1990 and the Pfeffer's scenarios were calculated for 2100 , value 110 was inserted in the equation as projection time.

The sums of the values obtained from the Pfeffer equation and the mean sea level value in Cananéia in 1990 and the highest tide are listed in table 6 . Table 7 presents the values for the areas covered by the highest tide in 2100, according to Pfeffer's scenarios.

\subsubsection{Pfeffer's modeling for 2100}

In this item the maps prepared for 2100 are presented for the overlapping of Scenario 1, Scenario 2 and Scenario 3 (Fig. 10).

\subsubsection{Application of Ramhstorf's model}

Ramhstorf's equation (Eq. 3) was applied using the value $0.25 \mathrm{~cm}$ in the Local Factor field of mean sea level rise in Cananéia. The results from this equation were added to the mean sea level recorded in the Cananéia tide gauge in 1990 $(1.72 \mathrm{~m})$. The result of the equation applied to the Ramhstorf's scenarios can be seen in table 8. Similarly to Pfeffer's equation, as the reference year is 1990 and the Ramhstorf's Scenarios were calculated for 2100 , the value 110 was inserted in the equation as projection time.

The sums of the values obtained from Ramhstorf's equation, plus the mean sea level in Cananéia (in 1990) and the highest tide are listed in table 9 . Table 10 the values of the areas covered by the highest tide in 2100 .

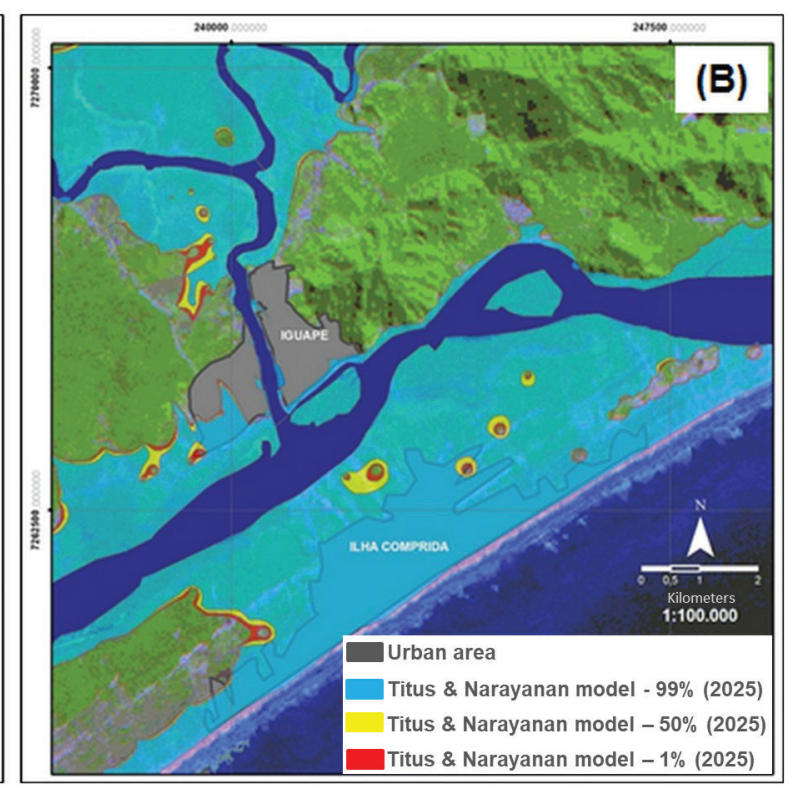

Figure 7. Titus and Narayanan model for the year 2025. A) Cananéia-Iguape Estuarine-Lagoonal Complex; B) Urban areas of Iguape and Cananéia Municipalities. Background image: Landsat TM from 19th November 2010 (Map reference system - UTM, zone 23S; datum - SIRGAS 2000).

Figura 7. Modelo de Titus e Narayanan para o ano de 2025. A) Complexo Estuarino Lagunar Cananéia-Iguape; B) áreas urbanas dos municípios de Iguape e Canaéia. Imagem de fundo: Landsat TM de 19/11/2010 (Sistema de referência UTM, zona 23S; datum - SIRGAS 2000). 

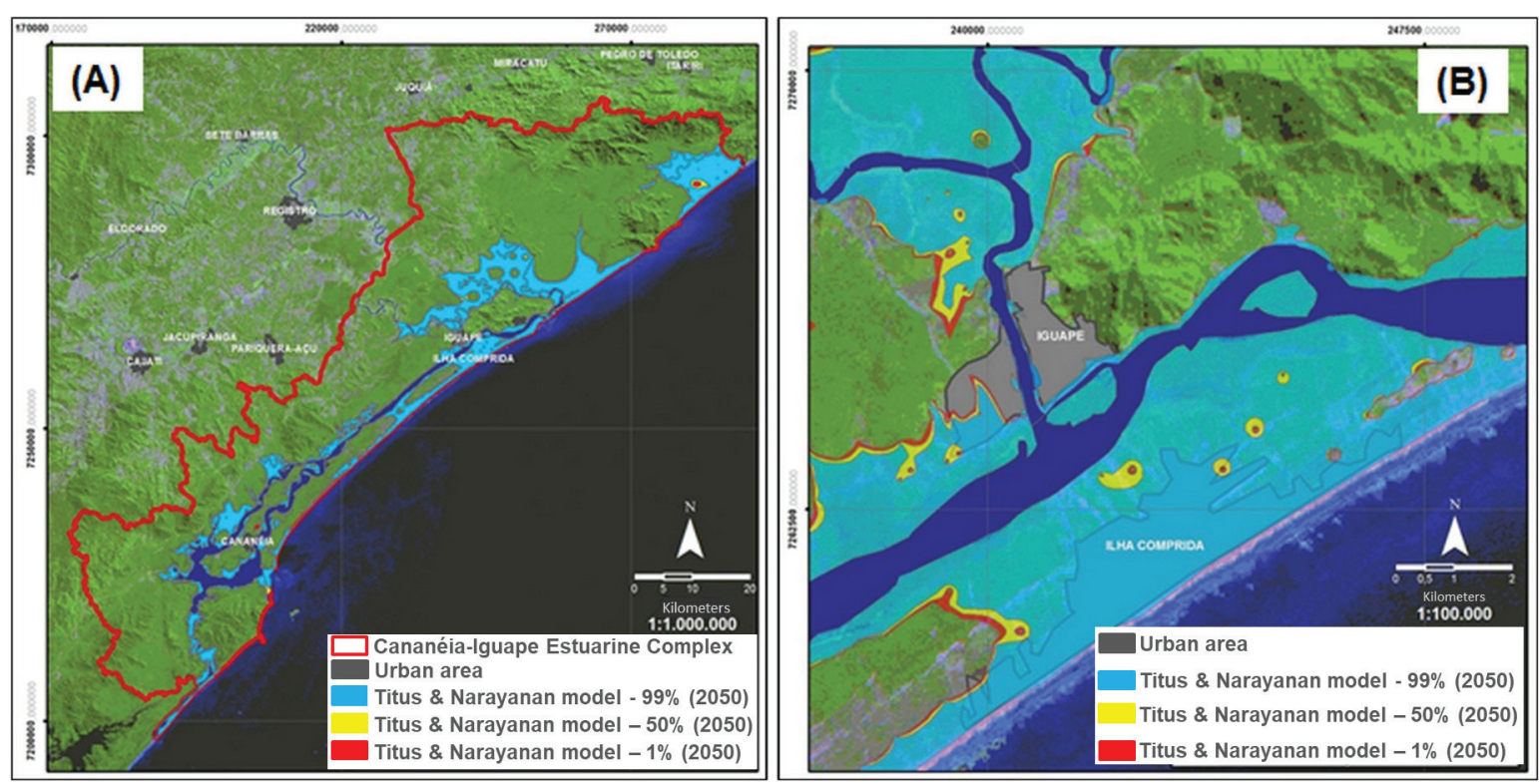

Figure 8. Titus and Narayanan model for the year 2050. A) Cananéia-Iguape Estuarine-Lagoonal Complex; B) Urban areas of Iguape and Cananéia Municipalities. Background image: Landsat TM from 19th November 2010 (Map reference system - UTM, zone 23S; datum - SIRGAS 2000).

Figura 8. Modelo de Titus e Narayanan para o ano de 2050. A) Complexo Estuarino Lagunar Cananéia-Iguape; B) áreas urbanas dos municípios de Iguape e Canaéia. Imagem de fundo: Landsat TM de 19/11/2010 (Sistema de referência UTM, zona 23S; datum - SIRGAS 2000).
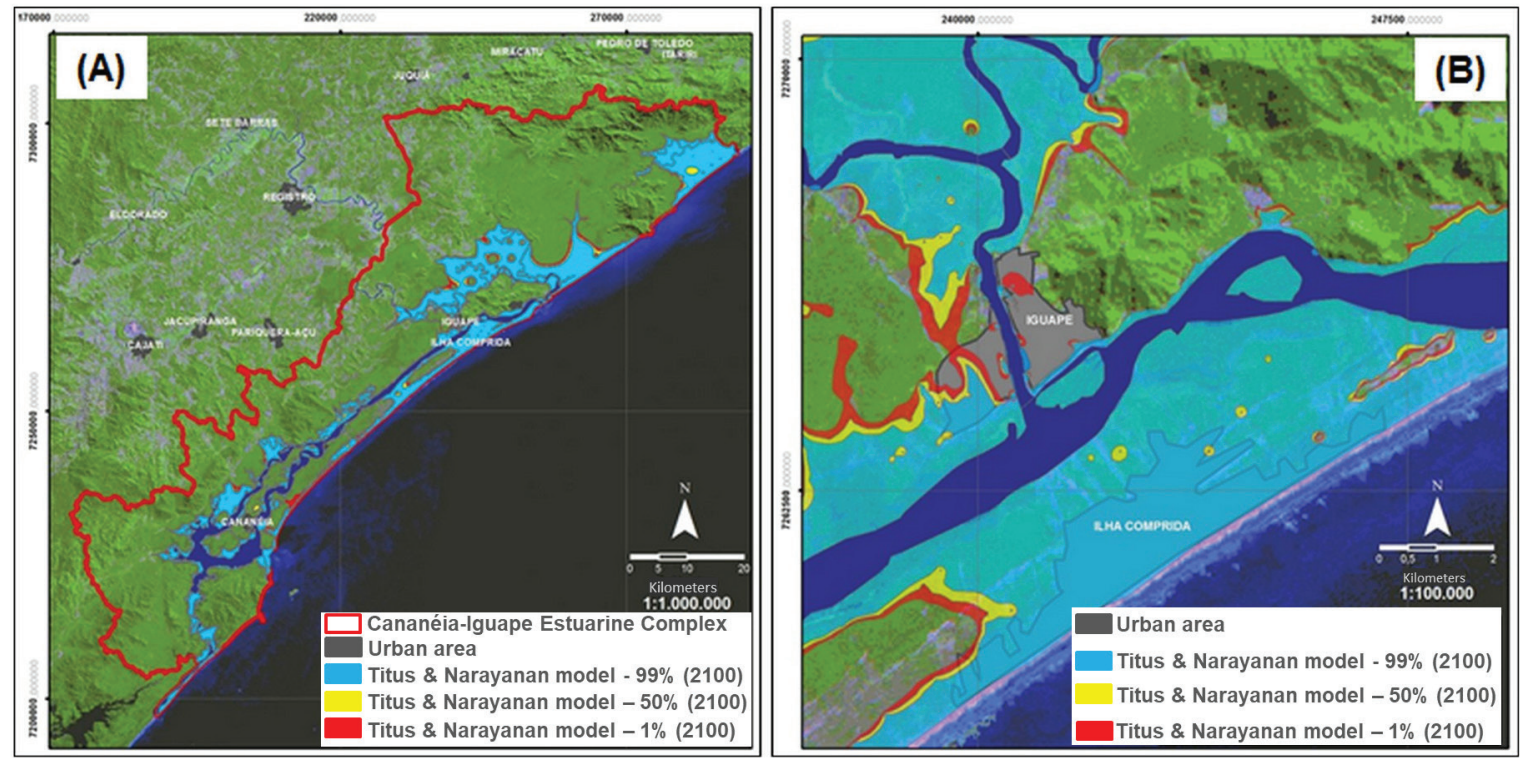

Figure 9. Titus and Narayanan model for the year 2100. A) Cananéia-Iguape Estuarine-Lagoonal Complex; B) Urban areas of Iguape and Cananéia Municipalities. Background image: Landsat TM from 19th November 2010 (Map reference system - UTM, zone 23S; datum - SIRGAS 2000).

Figura 9. Modelo de Titus e Narayanan para o ano de 2100. A) Complexo Estuarino Lagunar Cananéia-Iguape; B) áreas urbanas dos municípios de Iguape e Cananéia. Imagem de fundo: Landsat TM de 19/11/2010 (Sistema de referência UTM, zona 23S; datum - SIRGAS 2000).Complex; B) Urban areas of Iguape and Cananéia Municipalities. Background image: Landsat TM from 19th November 2010 (Map reference system - UTM, zone 23S; datum - SIRGAS 2000). 
Table 5. Results from Equation $2(\mathrm{~cm})$.

Tabela 5. Resultados da Equação 2 (cm).

\begin{tabular}{cc}
\hline Scenarios & $\mathbf{2 1 0 0}$ \\
\hline Global rise of $78.5 \mathrm{~cm}$ & 106 \\
Global rise of $83.3 \mathrm{~cm}$ & 110.8 \\
Global rise of $200.8 \mathrm{~cm}$ & 228.3 \\
\hline
\end{tabular}

Table 6. Results from adding the values obtained with the application of Pfeffer equation, mean sea level in 1990 and highest tide $(\mathrm{cm})$.

Tabela 6. Resultado da adição dos valores obtidos com a aplicação da equação de Pfeffer ao nível médio do mar em 1990 e maré mais alta $(\mathrm{cm})$.

\begin{tabular}{cc}
\hline Scenarios & $\mathbf{2 1 0 0}$ \\
\hline Global rise of $78.5 \mathrm{~cm}$ & 409 \\
Global rise of $83.3 \mathrm{~cm}$ & 414 \\
Global rise of $200.8 \mathrm{~cm}$ & 531 \\
\hline
\end{tabular}

Table 7. Areas flooded by the highest tide in 2100 from Pfeffer's scenarios $\left(\mathrm{km}^{2}\right)$.

Tabela 7. Áreas inundadas pela maré mais alta em 2100, cenários de Pfeffer $\left(\mathrm{km}^{2}\right)$.

\begin{tabular}{cc}
\hline Scenarios & $\mathbf{2 1 0 0}$ \\
\hline Global rise of $78.5 \mathrm{~cm}$ & 552 \\
Global rise of $83.3 \mathrm{~cm}$ & 558 \\
Global rise of $200.8 \mathrm{~cm}$ & 675 \\
\hline
\end{tabular}

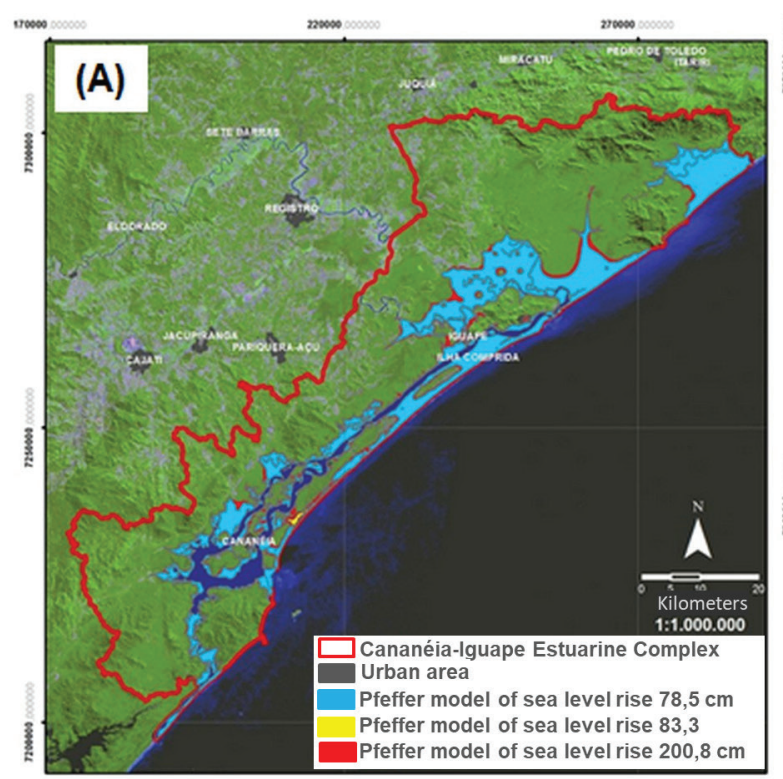

Table 8. Results from adding the values obtained from the application of Ramhstorf's equation (cm).

Tabela 8. Resultado da adição dos valores obtidos da aplicação da equação de Ramhstorf (cm).

\begin{tabular}{cc}
\hline Scenarios & $\mathbf{2 1 0 0}$ \\
\hline Global rise of $0.5 \mathrm{~m}$ & 250 \\
Global rise of $1.4 \mathrm{~m}$ & 340 \\
\hline
\end{tabular}

Table 9. Results from adding the values obtained from the application of Ramhstorf's equation, mean sea level in 1990, to the highest tide (cm).

Tabela 9. Resultado da adição dos valores obtidos com a aplicação da equação de Ramhstorf ao nível médio do mar em 1990 e maré mais alta $(\mathrm{cm})$.

\begin{tabular}{cc}
\hline Scenarios & $\mathbf{2 1 0 0}$ \\
\hline Global rise of $0.5 \mathrm{~m}$ & 380 \\
Global rise of $1.4 \mathrm{~m}$ & 470 \\
\hline
\end{tabular}

Table 10. Areas flooded by the high tide in 2100 for Ramhstorf's scenarios $\left(\mathrm{km}^{2}\right)$.

Tabela 10. Áreas inundadas pela maré mais alta em 2100, cenários de Ramhstorf $\left(\mathrm{km}^{2}\right)$.

\begin{tabular}{cc}
\hline Scenarios & $\mathbf{2 1 0 0}$ \\
\hline Global rise of $0.5 \mathrm{~m}$ & 527 \\
Global rise of $1.4 \mathrm{~m}$ & 607 \\
\hline
\end{tabular}

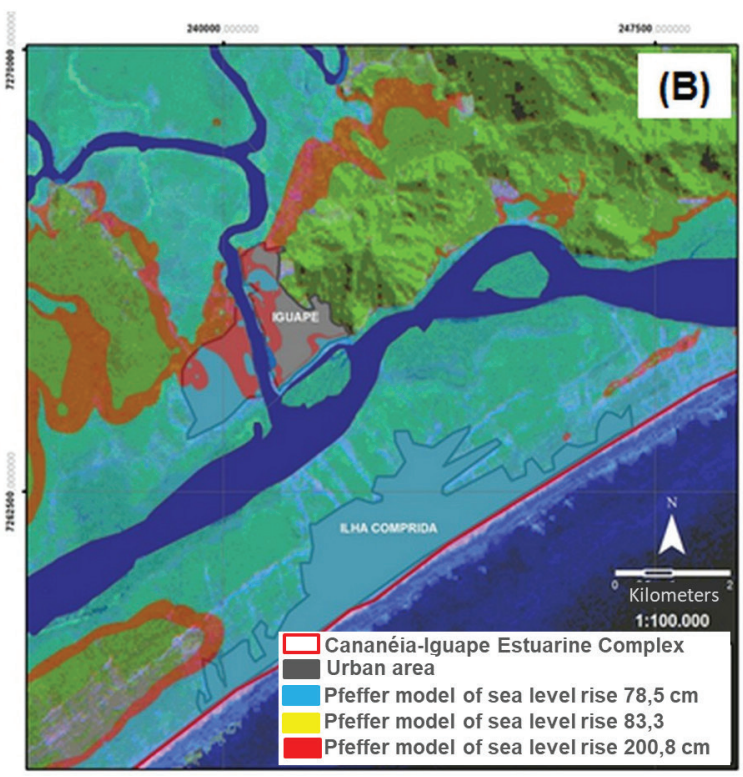

Figure 10. Pfeffer model for the year 2100. A) Cananéia-Iguape Estuarine-Lagoonal Complex; B) Urban areas of Iguape and Cananéia Municipalities. Background image: Landsat TM from 19th November 2010 (Map reference system - UTM, zone 23S; datum - SIRGAS 2000).

Figura 10. Modelo de Pfeffer para o ano de 2100. A) Complexo Estuarino Lagunar Cananéia-Iguape; B) áreas urbanas dos municípios de Iguape e Cananéia. Imagem de fundo: Landsat TM de 19/11/2010 (Sistema de referência - UTM, zona 23S; datum - SIRGAS 2000). 


\subsubsection{Ramhstorf's modeling for 2100}

The following maps prepared for 2100 show a potential global sea level rise of 0.5 or 1.4 m (Fig. 11).

\subsubsection{Application of the IPCC model}

Similarly to Pfeffer and Ramhstorf models, we used in the IPCC model the value $0.25 \mathrm{~cm}$ in the Local Factor field of mean sea level rise in Cananéia (Eq. 4). The sums of the values obtained using the equation of the IPCC model and the value of the mean sea level in Cananéia in 1990 and the highest tide are listed in table 11. The values of the areas covered by the highest tide in 2100 are shown in table 12.

\subsubsection{IPCC Modeling for 2100}

The maps prepared for 2100 reveal a potential global sea level rise of $0.18 \mathrm{~m}$ or 0.59 m (Fig. 12).

3.2 Indication of land use and occupation classes affected by a potential sea level rise in 2025 in the Cananéia-Iguape EstuarineLagoonal Complex (CIELC)

3.2.1 Overlapping of the $\mathrm{CECl}$ limit to the simulation for 2025

The limit of the Cananéia-Iguape EstuarineLagoonal Complex was overlapped to the simulation map of the UGRHI-11 land use and occupation classes in 2025 (Fig. 13).

\subsubsection{Overlap/crossing of the Titus and Narayanan's results on the 2025 map}

The areas affected by the highest tide in 2025, which resulted from Titus \& Narayanan (1995) equation (Eq. 1) were overlain to the land use and occupation map simulated for 2025. These flooding areas for the three scenarios calculated for the Titus and Narayanan's model were used to trim the 2025 map (Fig. 14). Thus, it was possible to quantify the areas affected in each scenario for 2025.
Table 11. Results from adding the values obtained from the application of the IPCC equation, mean sea level in 1990, and the highest tide $(\mathrm{cm})$.

Tabela 11. Resultado da adição dos valores obtidos com a aplicação da equação de IPCC ao nível médio do mar em 1990 e maré mais alta (cm).

\begin{tabular}{cc}
\hline Scenarios & $\mathbf{2 1 0 0}$ \\
\hline Global rise of $0.18 \mathrm{~m}$ & 348 \\
Global rise of $0.59 \mathrm{~m}$ & 389 \\
\hline
\end{tabular}

Table 12. Areas flooded by the highest tide in 2100 for IPCC scenarios $\left(\mathrm{km}^{2}\right)$.

Tabela 12. Áreas inundadas pela maré mais alta em 2100, cenários do IPCC $\left(\mathrm{km}^{2}\right)$.

\begin{tabular}{cc}
\hline Scenarios & $\mathbf{2 1 0 0}$ \\
\hline Global rise of $0.18 \mathrm{~m}$ & 498 \\
Global rise of $0.59 \mathrm{~m}$ & 535 \\
\hline
\end{tabular}

Table 13 lists the areas in $\mathrm{km}^{2}$ and percentage of the land use and occupation classes that supposedly could be flooded by a highest tide event in 2025. The percentages (1\%, $50 \%$ and $99 \%$ ), according to Titus \& Narayanan (1995), represent the possibility of the event taking place.

When comparing the areas and classes affected by a highest tide event in 2025 with the data from 1999 (Tab. 14), it is observed that the flooded area increases with time. However, observing the Titus and Narayanan's scenarios, the area decreases as the probability of the event taking place increases.

Considering the total area of the CananéiaIguape Estuarine-Lagoonal Complex (3,414.8 $\mathrm{km}^{2}$ ) and the areas affected by the highest tide recorded in 1999 and predicted for 2025, the percentage of each event in relation to the total area is shown in table 15.

\section{Discussion}

The results of the application of all models used in this project is corroborated by Rahmstorf's (2006) observation that the IPCC model is too conservative and does not properly reflect the uncertainty in relation to the calving of ice mantles in Greenland and Antarctica. Comparing the results of the most pessimistic projections for all models, the lowest result obtained is for the IPCC equation (Tab. 16). The comparison between the 

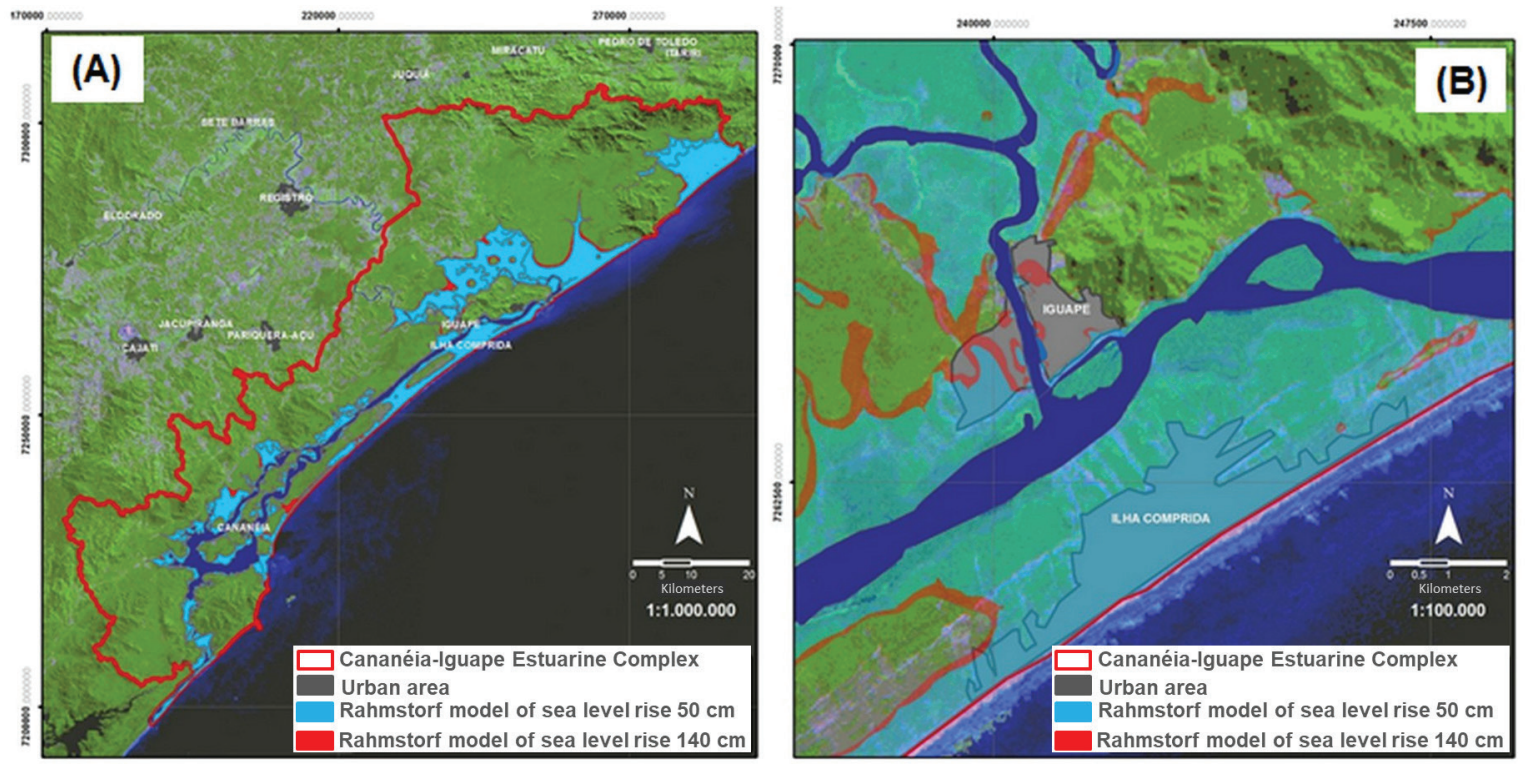

Figure 11. Ramhstorf model for the year 2100. A) Cananéia-Iguape Estuarine-Lagoonal Complex; B) Urban areas of Iguape and Cananéia Municipalities. Background image: Landsat TM from 19th November 2010 (Map reference system - UTM, zone 23S; datum - SIRGAS 2000).

Figura 11. Modelo de Ramhstorf para o ano de 2100. A) Complexo Estuarino Lagunar Cananéia-Iguape; B) áreas urbanas dos municípios de Iguape e Cananéia. Imagem de fundo: Landsat TM de 19/11/2010 (Sistema de referência - UTM, zona 23S; datum - SIRGAS 2000).
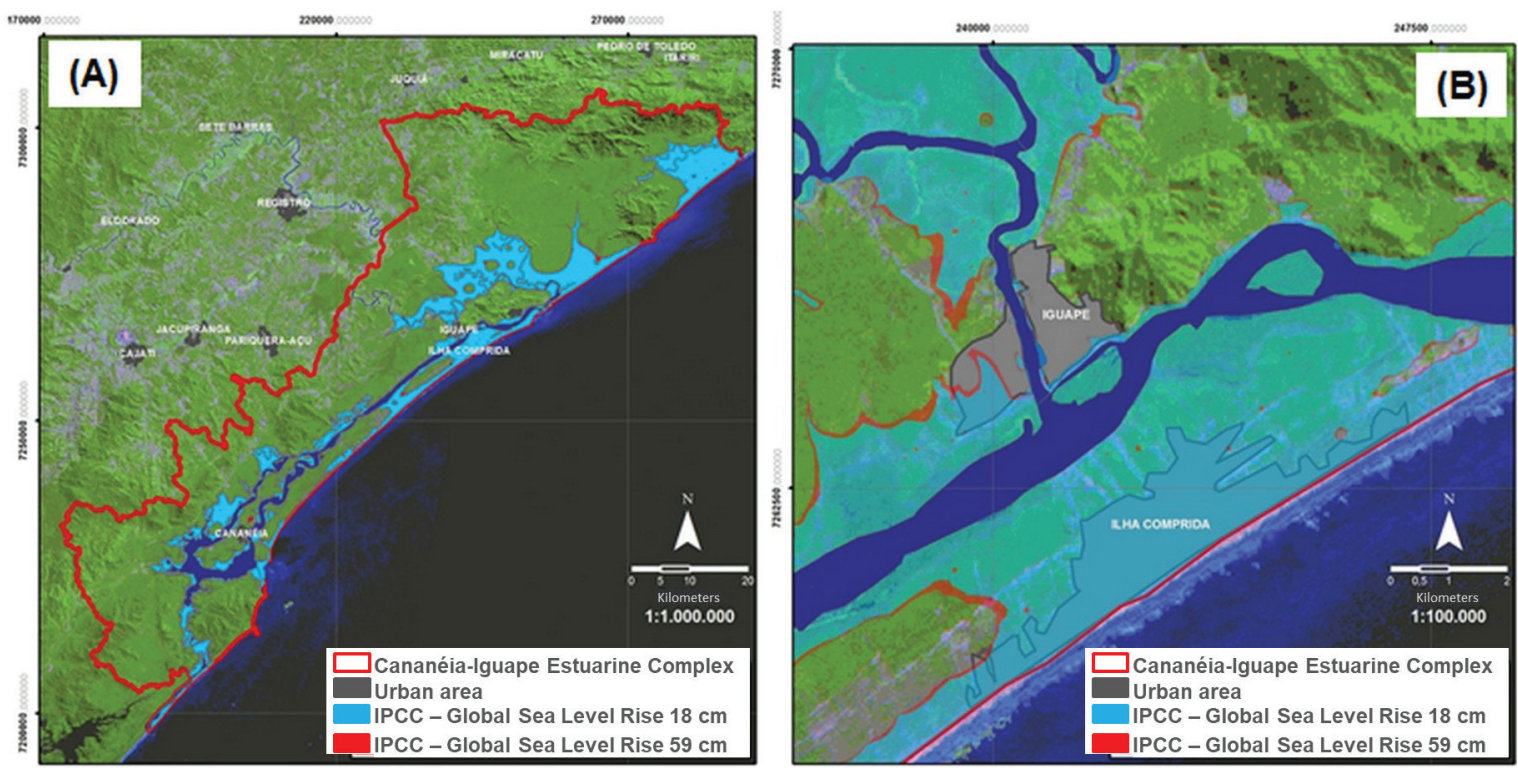

Figure 12. IPCC model for the year 2100. A) Cananéia-Iguape Estuarine-Lagoonal Complex; B) Urban areas of Iguape and Cananéia Municipalities. Background image: Landsat TM from 19th November 2010 (Map reference system - UTM, zone 23S; datum - SIRGAS 2000).

Figura 12. Modelo de IPCC para o ano de 2100. A) Complexo Estuarino Lagunar Cananéia-Iguape; B) áreas urbanas dos municípios de Iguape e Cananéia. Imagem de fundo: Landsat TM de 19/1 1/2010 (Sistema de referência - UTM, zona 23S; datum - SIRGAS 2000). 


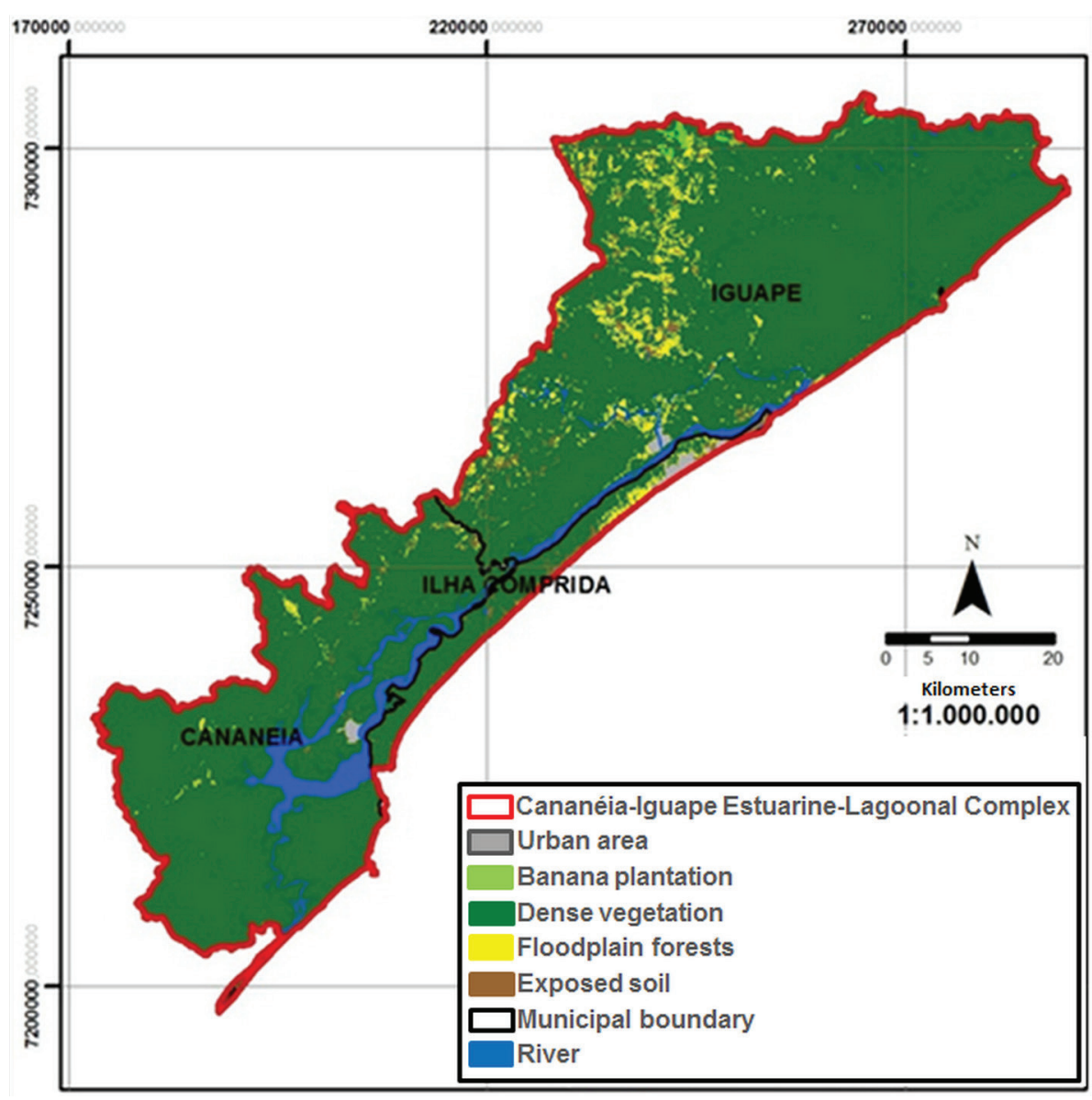

Figure 13. Land use and occupation classes in 2025 (Map reference system - UTM, zone 23S; datum - SIRGAS 2000). Figure 13. Classes de uso e ocupação do solo em 2025 (Sistema de referência - UTM, zona 23S; datum - SIRGAS 2000).

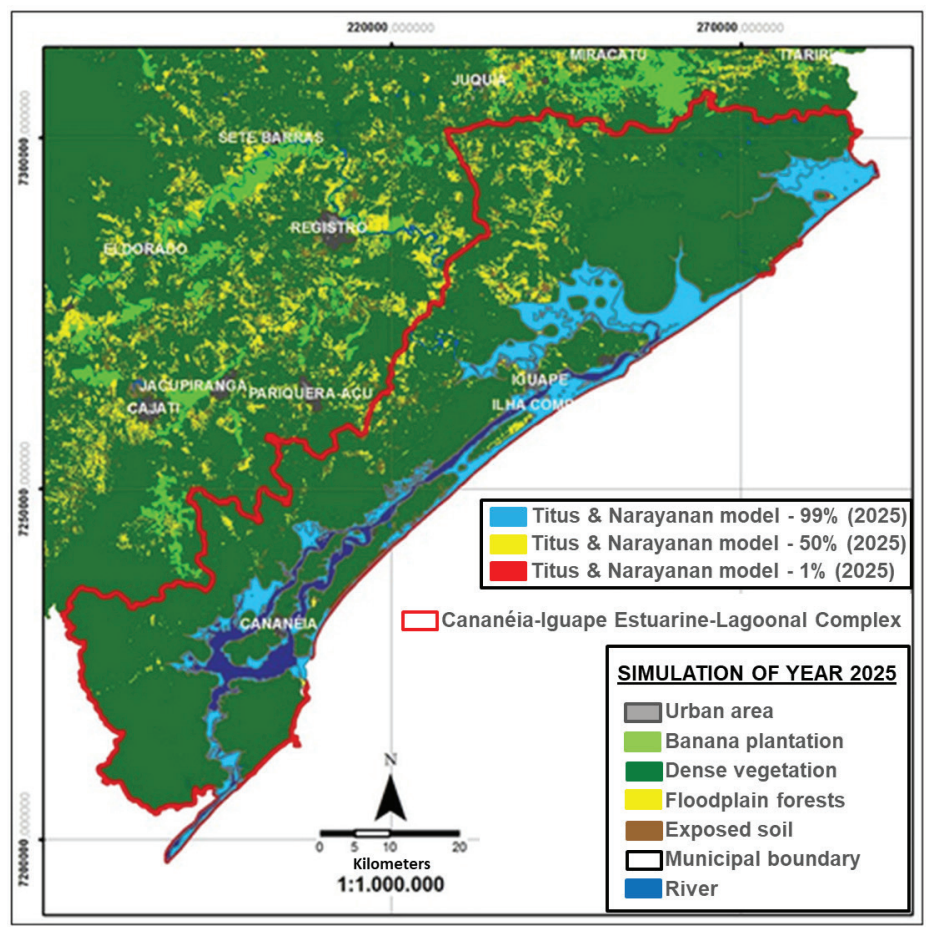

Figure 14. Titus and Narayanan's scenarios overlapped on the land use and occupation map for 2025 (Map reference system - UTM, zone 23S; datum - SIRGAS 2000).

Figura 14. Cenários de Titus e Narayanan sobrepostos ao mapa de uso e ocupação do solo para 2025 (Sistema de referência - UTM, zona 23S; datum - SIRGAS 2000). 
Table 13. Areas of the land use and occupation classes that supposedly could be flooded by a highest tide event in 2025. Tabela 13. Áreas das classes de uso e ocupação do solo que supostamente poderiam ser inundadas por um evento de maré alta em 2025.

\begin{tabular}{lcccccc}
\hline \multirow{2}{*}{ CLASSES } & \multicolumn{2}{c}{$\mathbf{9 9 \%}$} & \multicolumn{2}{c}{$\mathbf{5 0 \%}$} & \multicolumn{2}{c}{$\mathbf{1 \%}$} \\
& $\mathbf{k m}^{\mathbf{2}}$ & $\mathbf{( \% )}$ & $\mathbf{k m}^{\mathbf{2}}$ & $\mathbf{( \% )}$ & $\mathbf{k m}^{\mathbf{2}}$ & $\mathbf{( \% )}$ \\
\hline Urban area & 13.10 & 2.89 & 13.41 & 2.84 & 13.64 & 2.80 \\
Dense arboreal vegetation & 389.15 & 85.91 & 406.25 & 86.07 & 419.84 & 86.21 \\
Floodplain or campo sujo vegetation & 22.02 & 4.86 & 23.03 & 4.88 & 23.72 & 4.87 \\
Exposed soil & 28.73 & 6.34 & 29.32 & 6.21 & 29.80 & 6.12 \\
Total flooded area & 453 & 100 & 472 & 100 & 487 & 100 \\
\hline
\end{tabular}

Table 14. Land use and occupation classes, supposedly flooded by a highest tide event in 1999. Tabela 14. Áreas das classes de uso e ocupação do solo que supostamente poderiam ser inundadas por um evento de maré alta em 1999.

\begin{tabular}{ccc}
\hline CLASSES & $\mathbf{k m}^{\mathbf{2}}$ & $\mathbf{( \% )}$ \\
\hline Urban Area & 8.05 & 1.78 \\
Dense arboreal vegetation & 365.76 & 80.92 \\
Floodplain or campo sujo vegetation & 34.49 & 7.63 \\
Exposed soil & 43.66 & 9.66 \\
TOTAL AREA & 452 & 100 \\
\hline
\end{tabular}

Table 15. Percentage of flooded area with data recorded in 1999 and simulated for 2025.

Tabela 15. Porcentagem da área inundada com dados registrados em 1999 e simulados para 2025.

\begin{tabular}{ccc}
\hline Period & $\mathbf{k m}^{2}$ & $\mathbf{\%} \mathbf{C E C I}$ \\
\hline 1999 & 452 & 13.23 \\
$2025(99 \%)$ & 453 & 13.26 \\
$2025(50 \%)$ & 472 & 13.82 \\
$2025(1 \%)$ & 487 & 14.26 \\
CECI Area & 3415 & \\
\hline
\end{tabular}

Table 16. Projection of all models for the highest tide in 2100.

Tabela 16. Projeção de todos os modelos para o nível da maré mais alta em 2100.

\begin{tabular}{cc}
\hline MODELS & PROJECTION - 2100 (cm) \\
\hline IPCC & 389 \\
PFEFFER & 531 \\
RAMHSTORF & 470 \\
TITUS AND NARAYANAN & 441 \\
\hline
\end{tabular}


area affected for each method in 2100 applying the most pessimistic scenarios (models) can be visualized in figure 15.

In 1999 the land use and occupation classes of the Cananéia-Iguape EstuarineLagoonal Complex affected by a highest tide event, in decreasing order of size are: dense arboreal vegetation; exposed soil; floodplain or campo sujo vegetation, and urban area.

In the simulation of the land use and occupation for 2025 , this hierarchy is repeated in the three Titus \& Narayanan's (1995) scenarios. Obviously the areas of the classes will increase, as the flooding areas will increase. The flooding areas resultant from Titus \& Narayanan's (1995) scenarios are extreme events, because the highest tide was considered in the calculations. The daily variation of the mean sea level recorded in the Cananéia tide gauge is $-0.1 \mathrm{~m}$ to $1.3 \mathrm{~m}$.
The differences between the classes affected by the highest tide both in 1999 and 2025 agree with the representability of each class in the land use and occupation maps of such years. In 1999, the dense arboreal vegetation class represented $84.43 \%$ of the total area of the Cananéia-Iguape Estuarine-Lagoonal Complex $\left(3,414 \mathrm{~km}^{2}\right)$ and this same class represents $80.92 \%$ of the total flooded area $\left(452 \mathrm{~km}^{2}\right)$ in 1999.

According to the simulated land use and occupation map for 2025, the dense arboreal vegetation class will continue to expand, reaching $86.61 \%$ of the Cananéia-Iguape EstuarineLagoonal Complex. Titus and Narayanan (1995) most optimistic scenario represents a flooded area of $453 \mathrm{~km}^{2}$, whereas the most pessimist of $487 \mathrm{~km}^{2}$. Considering the pessimistic scenario, $86.21 \%$ of the flooded area in 2025 will be composed of dense arboreal vegetation.

\section{HIGHER TIDE LEVEL IN 2100}

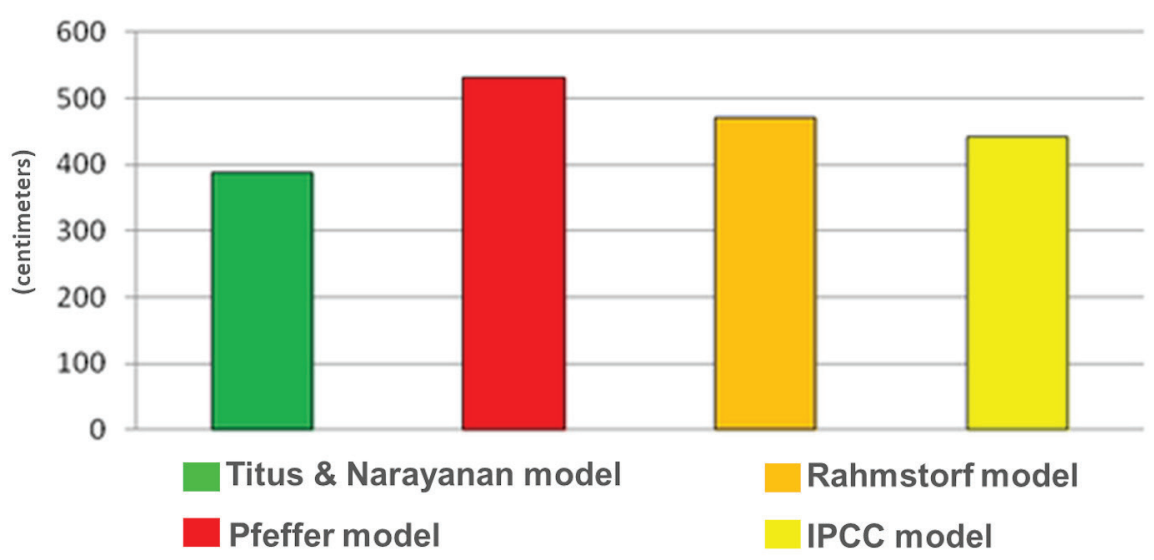

Figure 15. Projection of all methods for the highest tide in $2100\left(\mathrm{~km}^{2}\right)$.

Figura 15. Projeção de todos os métodos para o nível da maré mais alta em $2100\left(\mathrm{~km}^{2}\right)$.

\section{Conclusions}

The use of different types of geotechnological tools was successful, integrating different working "fronts", which were at first independent: Cananéia-Iguape EstuarineLagoonal Complex land use mapping and simulation of the 2025 scenario and calculation of the vulnerability at a potential sea level rise (2025, 2050 and 2100). Thus, it was possible to aggregate all these products and prepare a final product, the quantification of the areas of land use and occupation classes of the CananéiaIguape Estuarine-Lagoonal Complex in 2025.

In the period of the study (1986, 1999 and 2010) the most representative UGRHI- 11 soil use and cover classes were: densearboreal vegetation, floodplain/campo sujo/anthropic field vegetation and exposed soil, which is in agreement with the study developed by Amaral (2010), who analyzed the land use evolution of the Pariquera-Açu Sheet (SG23-V-A-IV-1) between 1988 and 2008. 
In the first stage (1986-1999) there was a decrease of $497 \mathrm{~km}^{2}$ of the area of the dense arboreal vegetation class and inversely an increase of $504 \mathrm{~km}^{2}$ of the area of the exposed soil class, which supposedly represents the period of opening of some agricultural fronts. In the second stage (1999-2010) the opposite was observed, once an increase of $655 \mathrm{~km}^{2}$ occurred in the dense arboreal vegetation class that, probably by ecological succession, gained the areas of the floodplain/campo sujo/anthropic field vegetation and exposed soil classes, which lost $318 \mathrm{~km}^{2}$ and $143 \mathrm{~km}^{2}$, respectively. It is possible that the dense arboreal vegetation class also encompassed small-scale pasture and agriculture areas.

In the last stage (1999-2010) this possible succession of floodplain/capoeira/anthropic field and exposed soil classes to dense arboreal vegetation was explained by Amaral (2010) not as a result of the advance of inspection and/or conservation of these areas, but by the large rural exodus that occurred in the second stage.

From the scenario simulated for land use and occupation in 2025, should the trend studied between 1986 and 2010 not change, the Ribeira do Iguape Valley and the Southern Coast of the State of São Paulo will continue to be a region with a great area of dense arboreal vegetation, class that will represent $84.5 \%$ of the total area. Banana farming, which is a strong income for the region, will continue to expand, reaching six times the area of 1986. This growth of the banana farming and exposed soil areas, probably triggered by new agricultural fronts, will be towards the floodplain or campo sujo vegetation areas, which will lose $36 \%$ of their combined area.

According to the final map simulation, the dense arboreal vegetation class will represent $86.61 \%$ of the Cananéia-Iguape EstuarineLagoonal Complex in the most pessimistic scenario of Titus \& Narayanan (1995), and $86.21 \%$ of the flooded area in 2025 will be composed of dense arboreal vegetation. In 1999, 80.92\% of the flooded area was composed of dense arboreal vegetation. It is concluded that this expansion of the dense arboreal vegetation area in 2025 will also take place towards the coastal zone. Regarding the urban areas, the Ilha Comprida municipality may be the most affected, because practically the whole urban area will be covered by the sea at a highest tide event in 2025. The Cananéia and Iguape urban areas would not undergo so much influence of the high tide.

The annual sea level rise calculated using data recorded along 52 years by the Cananéia tide gauge can have a geological contribution. Souza (1995) investigated the geological evolution of the Cananéia-Iguape coastal plain by means of geophysical methods, such as gravimetric, magnetometric, high-resolution continuous seismic profiling and sounding, and suggested the possibility of modern tectonic movements, corroborating the interpretations of Contijo-Pascutti et al. (2012). The analysis of the data obtained by Souza (op. cit.), mainly the gravimetric ones, made the identification of gravimetric highs and lows possible. The author observed in the latter a gap in the sedimentary cover, which led him to suppose the existence of a normal fault system with blocks tilting NW, thus defining the Cananéia graben of Cenozoic age.

Therefore, it is suggested that the difference of $2.51 \mathrm{~mm}$ in the sea level rise rate assigned as a local factor in the Cananéia-Iguape EstuarineLagoonal Complex can reflect a strong tectonic influence, so that not only sea level rise is taking place, but also the sinking of the plain as a result of modern tectonic movements. Further studies must be carried out in order to understand how much the local factor is dependent on the sea level rise and how much is influenced by the Cananéia graben.

Acknowledgment. The authors would like to thank CAPES for the Institutional Doctorate Scholarship of Fabrício Bau Dalmas; and CNPq by the Research Productivity Scholarship of Antonio Conceição Paranhos Filho (Process 304122/2015-7).

\section{References}

Angonese, J.G., Delgado, M.G. \& Sendra, J.B. 2010. Simulación de crecimiento urbano mediante evaluación multicriterio y TIG en el Gran San Miguel de Tucumán (Argentina). In: Ojeda, J., Pita, M.F. \& Vallejo, I (Coordenadores). Tecnologías de la Información Geográfica: La Información Geográfica al servicio de los 
ciudadanos. Secretariado de Publicaciones de la Universidad de Sevilla, Sevilla, p. 873-888.

Antrop, M. 2004. Landscape change and the urbanization process in Europe. Landscape and Urban Planning, 67(1-4): 9-26.

Barth, M.C. \& Titus, J.G. 1984. Greenhouse effect and sea level rise. Van Nostrand Reinhold, New York, 324p.

Carrero, R., Navas, F., Malvárez, G. \& Cáceres, F. 2010. Aplicabilidad de las TIG en la generación de escenarios de futuro para una gestión integrada de las zonas costeras. In: Ojeda, J., Pita, M.F. \& Vallejo, I. (Coordenadores). Tecnologías de la Información Geográfica: La Información Geográfica al servicio de los ciudadanos. Secretariado de Publicaciones de la Universidad de Sevilla, Sevilla, p. 716-727.

Clavero, I., Santos, M., Navarro, R., Guerrero, J.J., Cáceres, F. \& Moreira, J.M. 2010. Implementación de un sistema de escenarios futuros sobre el mapa de usos de suelo de Andalucía. In: Ojeda, J., Pita, M.F. \& Vallejo, I. (Coordenadores). Tecnologías de la Información Geográfica: La Información Geográfica al servicio de los ciudadanos. Secretariado de Publicaciones de la Universidad de Sevilla, Sevilla, p. 759-776.

Cohen, J. 1960. A coefficient of agreement for nominal scale. Educational and Psychological Measurement, 20(1): 37-46.

Dalmas, F.B., de Oliveira, F.R., da Silva, I.S., dos Santos, A.J., Paranhos Filho, A.C. \& Macedo, A.B. 2015. Development and assessment of an erosion and landslide predictive model for the coastal region of the State of São Paulo, Brazil. Pesquisas em Geociências, 42(2): 173186.

Eastman, J.R. 2006. Guide to GIS and Imaging Processing. IDRISI Andes Manual: Version 15.0. Worcester, MA, Clark Labs of Clark University.

ESRI. Environmental Systems Research Institute. 2010. ARCMap version 10. Environmental Systems Research Institute Inc. New York.

Fraile-Jurado, P. 2011. Análisis de las problemáticas asociadas a la espacialización, evolución y representación de niveles del mar presentes y futuros em Andalucía. Sevilla, 354p. Tese de doctorado, Posgrado en Geografía Física y Análisis Geográfico Regional, Universidad de Sevilla.

Fraile-Jurado, P., \& Ojeda-Zújar, J. 2013. The importance of the vertical accuracy of digital elevation models in gauging inundation by sea level rise along the Valdelagrana beach and marshes (Bay of Cádiz, SW Spain). GeoMarine Letters, 33(2-3), 225-230.

Fraile-Jurado, P., Sánchez Carnero, N., \& Ojeda Zújar, J. 2014. Sensibilidad del cálculo de los niveles medios del mar al método y período de las series temporales de los mareógrafos en los procesos de inundación: Valdegrana (Cádiz). Boletín de la Asociación de Geógrafos Españoles, 65, 59-70.

Florentino, H.O., Biscaro, A.F.V \& Passos, J.R.S. 2010. Funções sigmoidais aplicadas na determinação da Atividade Metanogênica Específica - AME. Revista Brasileira de Biometria, 28(1): 141-150.

Funahashi. K. 19891. On the approximate realization of continuous mappings by neural networks. Neural Network, (2): 183-192.

Gago, M. 2007. Concepções de passado como expressão de consciência histórica. Currículo sem Fronteiras, 7(1): 127-136.

Gontijo-Pascutti, A.H.F., Hasui, Y., dos Santos, M. \& de Souza, I.A. 2012. As Serras do Mar e da Mantiqueira. In: Hasui, Y (Ed.). Geologia do Brasil. Beca. São Paulo, p. 549-571.

Gordon, P. 1965. Théorie des chaînes de Markov finies et ses applications. Paris: Dunod, 130p.

Hasui, Y., Carneiro, C. D. R., de Almeida, F. F. M., \& Bartorelli, A. (Eds.). 2012. Geologia do Brasil. Editora Beca, São Paulo. 900p.

IBGE. Instituto Brasileiro de Geografia e Estatística. 2011. Censo demográfico 2010. Características da população e dos domicílios: resultados do universo. Rio de Janeiro: IBGE, 2011

IPCC. Intergovernmental Panel on Climate Change. 2007. Climate Change 2007: The Physical Science Basis. In: Solomon et al. (eds). Contribution of Working Group I to the Fourth Assessment Report of the Intergovernmental Panel on Climate Change. Cambridge Univ. Press, Cambridge.

IPCC. Intergovernmental Panel on Climate 
Change. 2010. Workshop on sea level rise and ice sheet instabilities. 21 - 24 June, 2010. Kuala Lumpur, Malaysia.

Jensen, J.R. 2011. Sensoriamento Remoto do Ambiente uma Perspectiva Em Recursos Terrestre. Editora Parentese, São José dos Campos SP. 598p.

Jolliffe, I. T. 2002. Principal component analysis, second edition. Springer Serires in Statistics.

Júnior, D.R.N., Giannini, P.C.F. \& Tanaka, A.P.B. 2008. Mudanças Morfológicas da Extremidade NE da Ilha Comprida (SP) nos Últimos Dois Séculos. Geologia USP - Série Científica, São Paulo, 8(1): 25-39.

Jurado, P.F. 2011. Análisis de las problemáticas asociadas a la espacialización, evolución y representación de niveles del mar presentes y futuros em Andalucía. Sevilla, 354p. Tese de doctorado, Posgrado en Geografía Física y Análisis Geográfico Regional, Universidad de Sevilla.

Kendall, M.G. \& Ord, J.K. 1990. Time series. Edward Arnold. London, England. 296p.

Landis, J.R. \& Kochsource, G.G. 1977. The Measurement of Observer Agreement for Categorical. Biometrics, 33(1): 159-174.

Melo, M. S. D. 1990. Formacao Pariquera-Açu e depositos relacionados: sedimentação, tectonica e geomorfogênese. 232p. Dissertação de Mestrado, Programa de Pósgraduação em Geologia Sedimentar. Instituto de Geociências, Universidade de São Paulo, São Paulo.

MMA. Ministério do Meio Ambiente. 2006. Diretrizes Metodológicas para o Zoneamento Ecológico-Econômico do Brasil. Parte 2. Brasília, DF. 29 p.

PMSL. Permanent Service For Mean Sea Level. 2017. Dados do marégrafo de Cananéia (1954-2006). 2017. Available from: <http:// www.psmsl.org/>. Cited 2017 Mar 5.

Ojeda Zújar, J., Sanchez, E., Fernandez-Palacios, A. \& Moreira, J.M. 1995. Study of the dynamics of estuarine and coastal waters using remote sensing: the Tinto-Odiel estuary, SW Spain. Journal of Coastal Conservation, 1(2): 109118.

Ojeda Zújar, J. 2000. Método para el cálculo de la erosión costera. Revisión, tendencias y propuesta. Boletín de la Asociación de Geógrafos Españoles, 30: 103-118.

Ojeda Zújar, J. \& Villar Lama, A. 2007. Evolución del suelo urbano/alterado en el litoral de Andalucía. GeoFocus, 7: 73-99.

Ojeda Zújar, J., Álvarez Francoso, J.I., Cajaraville Martín, D. \& Fraile Jurado, P. 2009. El uso de las TIG para el cálculo del Indice de Vulnerabilidad Costera (CVI) ante una potencial subida del nivel del mar en la costa andaluza (España). GeoFocus, 9: 83-100.

Pfeffer, W.T., Harper, J.T. \& O'neel, S. 2008. Kinematic Constraints on Glacier Contributions to 21st-Century Sea-Level Rise. Science Express, 321 (5894): 1340-1343.

Rahmstorf, S. 2006. A Semi-Empirical Approach to Projecting Future Sea-Level Rise. Science Express, 315(5810): 368-370.

Ramalho Filho, A. \& Beek, K.L. 1995. Sistema de avaliação de aptidão agrícola das terras. $3^{\circ} \mathrm{Ed}$ ver. - Rio de Janeiro: EMBRAPA - CNPS, 65p.

Ross, J.L.S. 2002. A morfogênese da bacia do rio Ribeira de Iguape e os sistemas ambientais. Geologia USP, 12: 20-39.

Souza, L.A.P. de. 1995. A planície costeira Cananéia - Iguape, litoral sul do Estado de São Paulo: Um exemplo de utilização de métodos geofisicos no estudo de áreas costeiras. São Paulo, 207p. Dissertação de Mestrado. Programa de Pós-Graduação em Oceanografia Geológica, Instituto Oceanográfico da Universidade de São Paulo.

Terra, T.N. 2010. Efeitos cumulativos e a construção de cenários em paisagens legalmente protegidas. Campinas, 114p. Tese de Doutorado. Programa de Pós-Graduação em Engenharia Civil. Universidade Estadual de Campinas.

Tide for Fishing. 2007. Cananéia tide gauge data. Available from: <https://tides4fishing.com/br/ so-paulo/cananeia >. Cited 2017 May 10.

Titus, J.G. \& Narayanan, V. K. 1995. The Probability of Sea Level Rise. Washington, D.C., Environmental Protection Agency. 197p.

Valente, R.O.A. \& Vettorazzi, C.A. 2008. Definition of priority areas for forest conservation through the ordered weighted averaging method. Forest Ecology and Management, 256(6): 1408-1417. 
Vieira, E.H.A. 2010. Conservação ambiental em cenários de uso: medidas de mudanças, heterogeneidade e valoração da paisagem. Campinas, 178p. Tese de Doutorado, Programa de Pós-Graduação em Engenharia Civil, Universidade Estadual de Campinas. 